\title{
Jakub Sawicki
}

\section{Analecta z rękopisów bibliotek warszawskich}

Prawo Kanoniczne : kwartalnik prawno-historyczny 3/1-2, 307-363

1960

Artykuł został zdigitalizowany i opracowany do udostępnienia w internecie przez Muzeum Historii Polski w ramach prac podejmowanych na rzecz zapewnienia otwartego, powszechnego i trwałego dostępu do polskiego dorobku naukowego i kulturalnego. Artykuł jest umieszczony w kolekcji cyfrowej bazhum.muzhp.pl, gromadzącej zawartość polskich czasopism humanistycznych i społecznych.

Tekst jest udostępniony do wykorzystania w ramach dozwolonego użytku. 


\title{
JAKUB S A W I C K I
}

\section{ANALECTA \\ Z REKOPISÔW BIBLIOTEK WARSZAWSKICH}

\author{
I.
}

\begin{abstract}
Rękopis Biblioteki Uniwersytetu Warszawskiego nr inw. 224.
\end{abstract}

W jednej $\mathrm{z}$ tek po Bolesławie Ulanowskim, wypożyczonej mi jeszcze przed wybuchem ostatniej wojny przez Polską Akademię Umiejętności w Krakowie do mego osobistego użytku do Warszawy, znajdował się sporządzony kaligraficznym ręcznym pismem odpis zawartości jakiegoś rękopisu prawniczego bez oznaczenia daty czy proweniencji. Odpis ten, zaznaczający starannie paginację oryginału, na pierwszym miejscu zawierał kopię statutów synodalnych poznańskich Andrzeja Łaskarza z około $1420 \mathrm{r}$. Stąd moje zainteresowanie się tym odpisem. Na arkuszu papieru, służącym za okładkę, figurowała notatka spisana ręką prof. Stanisława K utr z eb y: ,Z rękopisu hr. Zygmunta Pusłowskiego (opis rękopisu w tece opisów rękopisów)". Z tej ,tekki opisów rękopisów”, która w chwili wybuchu wojny również znajdowała się u mnie w Warszawie, nie pozostało śladu. Gdy więc opracowywałem do druku tom VII moich "Concilia Poloniae", poświęcony synodom diecezji poznańskiej ${ }^{1}$, starałem się dotrzeć do samego rękopisu. Zwró-

1 S awicki J., Concilia Poloniae. Źródta i studia krytyczne. VII. Synody diecezji poznańskiej $i$ ich statuty. Poznań 1952, ss. XII, 168, 2 tabl. 
ciłem się do zamieszkałego w Krakowie syna znanego zbieracza Zygmunta Pusłowskiego, p. Ksawerego Pusłowskiego z prośbą o informacje. Listem z 15 XI 1947 r. doniósł mi p. Ksawery Pusłowski, że ,,mój brat poległy na wojnie przewiózł niebacznie część biblioteki krakowskiej na wieś, gdzie została spalona. Przepadł cały dział samorządu - filozofia bardzo cenne zbiory. Tutaj została głównie genealogia i to włoska i francuska głównie - Wchodził kto chciał, brał i rozdawał - wiem o książkach, które zawędrowały do Rzymu, gdzte mieliśmy placówkę Akademii Umiejętności. Synody prowincjonalne miał św. p. Prof. Ulanowski, niestety nie moge ich odszukać - mogły przepaść na wsi". Uważając wobec takich informacji poszukiwany przeze mnie rękopis za stracony, zrezygnowałem $\mathrm{z}$ dalszych poszukiwań ${ }^{2}$, a przy opracowywaniu statutów biskupa Andrzeja Łaskarza z około 1420 r. posłużyłem się odpisem ocalałym $\mathrm{w}$ tece $\mathrm{U} \mathrm{l}$ anow s k i e g o.

Dnia $9 \times 1952 \mathrm{r}$. otrzymałem od jednego $\mathrm{z}$ nie znanych $\mathrm{mi}$ wtedy osobiście młodszych pracowników naukowych z Poznania list treści następującej: „Przeglądając wydaną niedawno w PTPN Pańską pracę dot. polskich synodów prowincjonalnych zauważyłem, że wzmiankując o rękopisie znajdującym się niegdyś $\mathrm{w}$ bibliotece $\mathrm{Z}$. Pusłowskiego $\mathrm{w}$ Krakowie, podaje $\mathrm{Pan}$ - na podstawie wiadomości od X. Pusłorwskiego - jakoby $w / w$ manuskrypt zaginął. Otóż wiadomość ta jest nieścisła, rękopis bowiem zachował się $\mathrm{i} w$ tej chwili jest u mnie. Rękopis ten wraz $z$ szeregiem druków o synodach (była to bodaj ze jedyna kolekcja tego rodzaju) zostal sprzedany w ubiegłym roku jednemu $\mathrm{z}$ mych krakowskich znajomych, który $\mathrm{z}$ kolei rozsprzedawał te rzeczy. Rękopis XV wieczny, ten właśnie, o którym Pan pisze, otrzymałem ja do sprzedania... Cena rękopisu 2,000. - zł. Brak okładki, zresztą doskonale zachowany".

Rękopisu tego oczywiście nie kupiłem, gdyż w moim przekonaniu zabytki takie nie powinny pozostawać $\mathrm{w}$ prywatnych rękach, lecz winny być zabezpieczone i udostępnione badaczom

2 Stosowną wzmiankę umieściłem w tomie VII Concilia Poloniae, 9 przyp. 19. 
w bibliotekach naukowych odpowiednio zorganizowanych. Natomiast nabyła rękopis ten Biblioteka Uniwersytetu Warszawskiego, w której pozostaje on pod nr inw. 224.

Rękopis omawiany pisany jest na papierze formatu $149 \times 204 \mathrm{~mm}$ kilkoma rękami z polowy XV wieku. Składa się z 3 seksternionów, liczy więc 36 kart, nie foliowanych. Kodeks ten posiadał kiedyś oprawę, dziś jest ona zdarta.

Współczesna ręka XX w. przeprowadzila ołówkiem paginację na nieparzystych stronnicach.

1. $\mathrm{Na}$ str. 1 - 24 spisane sa kaligraficznym pismem kodeksowym z pierwszej polowy XV w. pod nagłówkiem „Statuta diocesana ecclesie Poznaniensis"3 statuty synodalne diecezji poznańskiej biskupa Andrzeja Easkarza z około 1420 r.: Andreas Dei et apostolice sedis gratia episcopus Poznaniensis ad perpetuam rei memoriam. Quamvis humane debeat sufficere nature ad bene vivendum $><$ hec exigere et eum pro talibus interrogare.

Tekst ten opublikowal jako pierwszy Udalryk He y z m a n n w Starodawnych prawa polskiego pomnikach t. 5 (Kraków 1878) jako Supplementum pt. „Statuta Synodalia Andreae Episcopi Poznaniensis saeculo XV-mo confecta" Cracoviae A. 1878, z osobną paginacją rzymską I - XL. W tomie VII "Concilia Poloniae" ogłosilem w dodatku I (str. 129-142) rubryki oraz incipit i explicit poszczególnych artykułów omawianych statutów według rękopisu P (= Pusłowskiego) w zestawieniu $\mathrm{z}$ tekstami innych rękopisów, zaś w dodatku II (str. 143-161) pełny tekst tych statutów według rękopisu Biblioteki Uniwersytetu Wrocławskiego I Q 69 fol. 213-229 z uwzględnieniem wszystkich odmianek tekstowych z rękopisu P.

2. $\mathrm{Na}$ str. 25 - 26 ta sama ręka, która pisała tekst statutów synodalnych, spisała formularz mszalny p.t. „Missa contra scismaticos habetur in hunc modum". In primis dicantur septem psalmi cum letaniis $><$ preces placatus admitte, ut supra etc.

3 Na marginesie tego tekstu u samej góry str. 1 dopisała ręka z drugiej polowy XVI w.: "Fuerunt istae constitutiones sancitae Anno Domini 1461 vide Cromerus lib. 24 fol. 533". 
$\mathrm{Na}$ marginesie tego tekstu dopisała późniejsza ręka z drugiej polowy XVI w.: "Sancitum est sacrum istud anno Domini 1440 , vide Miechovitam libro $4^{\text {to }}$ cap. 57, cum facta fuit unio cum Ruthenis per Isidorum archiepiscopum Kioviensem, quem Moschus interemerat".

3. $\mathrm{Na}$ str. 27-41 ta sama ręka spisała obszerny formularz pytań dla świadków synodalnych, jakie stawiać winni archidiakoni wizytujący parafie. Tytuł tego zabytku brzmi: „Forma inquisitionis in visitatione archidiaconi in parrochiis". Fratres, nos sumus missi per dominum nostrum episcopum > <in octavam renovetur in pane recenti etc.

Zbliżony do omawianego tu pomnika tekst takiej „Exhortatio visitationis synodalis" ogłosil swego czasu Wladysław Abraham ${ }^{4}$ ręlkopisu Biblioteki Jagiellońskiej $w$ Krakowie $n r 348^{5}$. Rozpoznał on jej pochodzenie i przeznaczenie włocławskie, choć nie bez zgłoszenia pewnych wątpliwości. „Na tej podstawie formułujemy wniosek, - dowodził A b r a$\mathrm{h} \mathrm{a} \mathrm{m}^{6}$ - że dzisiejsza forma naszej instrukcji pochodzi z czasu między 1326 a 1360 , że więc już w czasach Kaźmierza W. w tej formie mogła być używaną. Nie jesteśmy wstanie natomiast rozstrzygnąc pytania, czy instrukcja ta jest diecezjalną włoclawską, czy też prowincjonalną gnieźnieńską, jej analogia ze statutami prowincjonalnymi przemawialaby za drugą możliwością, przeciwnie znowu wzmianka w toku instrukcji o biskupstwie włocławskim mogłaby świadczyć, że instrukcja jest diecezjalną włocławską".

Publikowana tu przez nas „Forma inquisitionis” pomnaża bardzo szczupły zasób tego rodzaju pomników, mających ważne znaczenie dla historii prawa ${ }^{7}$, o nową, ciekawą pozycję. Tak jak w instrukcji dla diecezji włocławsskiej pytanie: „, Item si qui

4 A braham W., Exhortatio visitationis synodalis $z$ diecezji wtockawskiej $z$ wieku XIV. - Arch. Kom. Hist. T. 5 (1889), 219-229 i odb. Kraków 1888, 15.

5 Opis tego rekopisu dał Helcel, Starod. Prawa Polsk. Pomn. T. 1 (1856), XII - XVI.

6 A b raham W., Exhortatio, o.c., 224.

7 Podkreślił to już A b r ham, o. c., 219. 
beneficiati se diu absentent a suis beneficiis absque licencia episcopi W 1 a d is l a viens i s" pozwoliło Abrahamowi odnieść publikowaną instrukcję do diecezji włocławskiej, tak i my naszą „Forma inquisitionis”, która w analogicznym pytaniu wymienia biskupa poznańskiego, możemy odnieść do diecezji poznańskiej, dla której niewątpliwie była przeznaczona.

Podobieństwo między instrukcją włocławską a poznańską jest zupelne. Ułożone są niewątpliwie na podstawie tego samego wzoru czy schematu. Przeważnie panuje zgodność dosłowna, zachowana jest również ta sama kolejność pytań.

Lecz są i odchylenia, których nie sposób wyjaśnić niedbalstwem kopisty, a które wykraczają poza normainy zwykle spotykany zakres drobniejszych omyłek, przestawień, opuszczeń lub dodatków o charakterze stylistycznym.

Dodano $w$ instrukcji poznańskiej kilka pytań, których brak w instrukeji włocławskiej:

a) "Quoniam pax est omnium et omnibus ultima $><$ cum affectu vindicte".

b) „Item si qui clerıci aut sacerdotes consueverunt inebriari sepe". To pytanie odnajdujemy natomiast w instrukcji pomezańskiej. ${ }^{8}$

c) Pięć ostatnich pytań „Item de aliis specialibus casibus vel excessibus > < renovetur in pane recenti etc". W instrukcji pomezańskiej również nie ma tych pytań. Przypuszczać należy, że są to lokalne dodatki poznańskie.

Poza tym widać $w$ tekście poznańskim kilka uzupełnien, bliżej objaśniających treść pytania. Np. w pytaniu: „Item, si sacerdotes exponunt populo in sermonibus capitulum: Omnis utriusque sexus" dodaje redakcja poznańska: ,id est, ut quilibet parrochianus in sua parrochia adminus semel in anno proprio confiteatur sacerdoti et alia percipiat sacramenta".

Stwierdzić możemy również kilka dość znamiennych opuszczeń. I tak opuszczono pytania:

8 Jacobson H. F., Geschichte der Quellen des katholischen Kirchenrechts der Provinzen Preussen und Posen. Königsberg 1837, (258). - Por. A b r a ha m, Exhortatio o. c., 222. 
„item si quis vir graviter uxorem suam tractat".

"Item si qui pacem vel treugas violaverint ordinatas".

"Item si qui sint beghardi vel beniguine, que post et contra factam prohibicionem a domino Clemente papa quinto statum beniguarum assumpserint".

Opuszczenia tych pytań wypada tłumaczyć poprostu odmienną sytuacją geograficzną i odmiennym okresem chronologicznym, w którym instrukcja ta miała mieć zastosowanie. Opuszczenie pewnych pytań lub dodanie czy rozbudowanie innych zależało od ich aktualności i przydatności. Rozpatrując te właściwości tekstu poznańskiego od tej właśnie strony, dochodzimy do przekonania, że jest on późniejszy czasowo od instrukcji włocławskiej i w tej ostatecznej formie, w której przekazal go nam omawiany rękopis, pochodzi z końca XIV lub poczatku XV wieku, w każdym razie jednak sprzed okresu walki z herezją husycką. Wśród pytań, które zostały $w$ redakcji poznańskiej uzupełnione, figuruje pytanie: „Item, si qui contraxerunt sponsalia vel matrimonia clandestine seu occulte absque solemnitate plebani vel vicarii sui". Instrukcja poznańska dodaje objaśnienie: „id est sine bannis”, a więc przesuwa punkt ciężkości na dopelnienie obowiązku zapowiedzi. Mogło się to stać najprawdopodobniej pod bezpośrednim wpływem statutów synodu prowincjonalnego w Kaliszu z 20 maja 1406 r., które $w$ art. 4 nakazały ściśle przestrzegać przepisów prawa powszechnego o głoszeniu zapowiedzi przed zawarciem małżeństwa. ${ }^{9}$ Przyjęcie tej możliwości wcale nie wyklucza znacznie odleglejszej metryki wzoru, na którym oparła się instrukcja poznańska.

Zbieżność obu tekstów, poznańskiego z włocławskim, jest oczywista. Lecz nie wydaje mi się, aby można bronić tezy o pochodzeniu tekstu poznańskiego od instrukcji włoclawskiej. Raczej wydaje nam się, że mamy tu do czynienia z dwiema od-

9 Caput 4: Item, quod capitulum ultimum de electione lib. VI de cridis ante institutionem, et cap. Quum inhibitio, de clandestina desponsatione, de bannis ante copulam praemittendis ad unguem observetur. - Hube R.: Antiquissimae constitutiones synodales provinciae Gneznensis. Petropoli 1856, 222. 
miennymi, samodzielnymi redakcjami lokalnymi, opierającymi się na wspólnym, dawniejszym wzorze zbieżnym w wielu punktach $z$ redakcją pomezańską. Do tego wniosku doprowadza nas nie tylko stwierdzenie, że $w$ instrukcji poznańskiej znalazło się pytanie, które figuruje w instrukcji pomezańskiej, a którego nie ma $w$ instrułcji włocławskiej, ale przede wszystkim sam fakt, że ten sam tekst, $\mathrm{z}$ drobnymi tylko zmianami, występuje $\mathrm{w}$ dwóch diecezjach tejże samej prowincji gnieźnieńskiej. Jakże trafne są spostrzeżenia A brahama, który stwierdził pewne wpływy prawa prowincjonalnego gnieźnieńskiego na niektóre sformułowania pytań instrukcji włocławskiej, ${ }^{10}$ i pod wplywem swych spostrzeżeń zawahał się, czy instrukcja przez niego ogłoszona jest diecezjalną włoclawską czy też prowincjonalną gnieźnieńską. Nie mial przed sobą tekstu poznańskiego. Dziś możemy natomiast twierdzić z wysokim stopniem prawdopodobieństwa, że musiał istnieć jakiś ogólny wzór, opracowany i obowiązujący w całej prowincji gnieźnieńskiej, odzwierciedlający ustawodawstwo i na nim opartą praktykę całej tej prowincji, zaś obie znane nam instrukcje, włocławska i poznańska, to $\mathrm{w}$ różnych okresach czasu dokonane adaptacje tej instrukcji prowincjonalnej do potrzeb lokalnych tych diecezji.

4. $\mathrm{Na} 42-49$ naszego rękopisu spisany jest odmienną ręką z połowy XV wieku ciekawy pomnik z pierwszej połowy $\mathrm{XV}$ wieku p.t. „Responsiones prelatorum et cleri Cracoviensis diocesis ad articulos dominorum nobilium r[egni] $\mathrm{P}$ [olonie] nuper presentatos".

Już pobieżne porównanie tego tekstu z podobnym zabytkiem p.t. "Concordata dominorum laicorum cum prelatis ecclesie. Anno 1440". opublikowanym przez Udalryka Heyzmanna w Starodaunych Prawa Polskiego Pomnikach T. 4. (1875) s. 95-100, pozwala stwierdzić znaczne i, jak mi się wydaje, dość znamienne różnice zarówno w tytule, jak i w samym tekście. Mamy tu niewątpliwie do czynienia $\mathrm{z}$ dwoma oddzielnymi, niezależnymi od siebie redakcjami tego elaboratu, który precyzuje stanowisko duchowieństwa diecezji krakow-

10 A b rah am W., Exhortatio, o. c., 224. 
skiej wobec grawaminów szlachty całego Królestwa. Sprawa sporów szlachty $\mathrm{z}$ duchowieństwem $\mathrm{w}$ pierwszych 4 dziesięcioleciach XV w. ma swoją bardzo ciekawą literaturę, że przypomnę tu nazwiska Bobrzyńskiegor1, Ula nowski ego $o^{12}$, Balzera ${ }^{13}$, Prochaski i $i^{14}$ H. F. Schmida ${ }^{15}$. Obecnie, przez odnalezienie publikowanego tu tekstu, dolącza się do prowadzonej dotąd dyskusji nowy element, który uczyni potrzebne podjęcie na nowo rozważań nad tym zagadnieniem w świetle nowrego źródła. Ramy niniejszej publikacji nie pozwalają na przeprowadzenie ponownej dyskusji, ani nawet na szczegółowe przedstawienie różnic między tymi tekstami. Ograniczam sie przeto do zasygnalizowania znaczenia odnalezionego zabytku dla badań naukowych nad XV-ym wiekiem i do opublikowania jego tekstu.

5. $\mathrm{Na}$ str. $49-52$, pod tytułem pisanym dużą frakturą „Sequitur copia privilegii regis Kazimiri super libertatione decimarum, emptione, venditione, locatione et conductione ipsarum", ręka tego samego pisarza, który skopiował omówione pod 4) „Responsiones prelatorum”, skopiowała dokument króla Kazimierza W. z daty Kraków 19 czerwea 1352 r.:16

11 Bobrzyński Mr, Wiadomość o uchwatach zjazdu piotrkowskiego $z$ r. 1406 oraz takiegoż zjazdu $z$ r. 1407. - Rozpr. wydz. histor.filozof. Akad. Umiejętn. T. 1 (1874), 108-123.

12 Ulanowski B., Laudum Vartense. - Rozpr wydz. hist. filozof. Akad. Umiejętn. T. 21 (1888), 173-313 i odb. Kraków 1887 ss. 1 nlb., 140; ten że, Zjazdy Piotrkowskie $z$ r. 1406 i $1407 i$ ich uchwa7y. - Rozpr. wydz. histor. - filozof. Akad. Umiejętn. T. 21 (1888), $314-344$ i odb. Kraków 1887, 31.

13 Ba lzer O., Laudum Cracoviense. - Przewodn. Nauk. i Liter. T. 16 (1888), 516-533, 600-611, 697-715 i W : Studia nad prawem polskim. Poznań 1889, 115-175.

14 Prochaska A., Konfederacja ziemian przeciwko duchowieństwu $w$ roku 1407. - Kwart. hist. R. 21: 1907, 292-308; t e nże, O dacie ugody małopolskiej duchowieństwa ze szlachta za biskupa Zbigniewa Oleśnickiego. - Rozpr. wydz. histor. - filoz. Akad. Umiejętn. T. 39 (1900), $131-150$ i odb. Kraków 1899, 20.

$15 \mathrm{Schmid} \mathrm{H.} \mathrm{F.,} \mathrm{Die} \mathrm{rechtlichen} \mathrm{Grundlagen} \mathrm{der} \mathrm{Pfarrorganisa-}$ tion auf westslawischem Boden und ihre Entwicklung während des Mittelalters. Weimar 1938, 779-788.

16 Kod. dypl. katedry krakowskiej cz. I (Mon. Medii Aevi Historica T. 1) Kraków 1874, 248-249 nr 195. 
In nomine Domini amen. Cum decime sint tributa egentium animarum, quas sibi Rex regum $><$ Actum et datum Cracovie XIII. Kal. iulii anno Domini millesimo CCCLII [1352]. Presentibus nobilibus $><$ Scriptum per notarium curie nostre Przibislaum et plebanum Sandeczen(sem).

6. Na str. 53 - 56 ten sam pisarz, który kopiował poprzedni dokument, przepisal dokument Kazimierza W. z daty Poznań 4 marca 1360 r.: ${ }^{17}$

Nos Kazimirus Dei gracia rex Polonie. Ad perpetuam [rei] memoriam et ad universorum, quorum interest noticiam presentibus volumus devenire, quod cupientes nemora, mericas, silvas et virgulta $><$ Actum Poznanie feria quarta post dominicam Reminiscere $1360><$ notarium curie nostre regalis.

7. Na str. 57 - 60 ta sama ręka skopiowała dokument arcybiskupa gnieźnieńskiego Mikołaja Kurowskiego z daty Gniezno, 25 kwietnia $1409 \mathrm{r} .{ }^{18}$

In nomine Domini amen. Nos Nicolaus divina providentia sancte Gneznensis ecclesie archiepiscopus una cum venerabilibus dominis> <Actum et datum Gnezne ipso die sancti Marci Evangeliste anno Domini millesimo $\mathrm{CCCC}^{0}$ IX $0><$ nobiscum capitulariter congregatis.

8. $\mathrm{Na}$ str. $60-62$ ta sama ręka, co poprzednio, kopiować rozpoczęła dokument arcybiskupa gnieźnieńskiego Jarosława $z$ daty Wieliczka 6 listopada 1361 r. ${ }^{19}$

Nos Jaroslaus divina providentia sancte Gnesnensis ecclesie archiepiscopus, in Cracoviensi diocesi in officio visitationis

17 Kod. dypl. wielkop. T. 3, 146-148 nr 1416. - Por. do tego Ul a nowski B., Laudum Vartense o. c. $279-282$.

18 Kod. dypl. wielkop. T. 5, 155 nn., nr 145. Polski przekład tego dokumentu - niedokładny, z rażącymi opuszczeniami i błędami w wyborze tekstów źródlowych, „Ruch husycki w Polsce”, opracowali Roman He ck i Ewa IM a I e c zyńska, Wrockaw 1953, 13-16 nr 10. Wydawcy dokument ten blędnie przypisują arcybiskupowi Mikolajowi $\mathrm{Trąbie.}$

19 Starodawne Prawa Polskiego Pomniki T. 1 (1856), 412 - 414; Kodeks katedry krakowskiej T. 1. 285-286. nr 225. 
constitutus $><$ tunc cessetur a divinis, ipso tamen de cimeterio vel ecclesia recedente - - na tym urywa się kopia u końca str. 62.

O tym, że kopia niniejsza, jak też i wszystkie poprzednie, sporządzona została na obszarze diecezji poznańskiej, świadczy charakterystyczna omyłka kopisty. W dokumencie Jarosława wymienione są strony w postępowaniu polubownym: „quod cum inter serenissimum principem dominum Kazimirum Dei gratia regem Polonie, et patronum nostrum ex una, et dominum Bodzantham fratrem nostrum carissimum episcopum poznaniensem" - tu pisarz spostrzegł się, iż wziął rozpęd zbyt. wielki, przekreślił wyraz „poznaniensem" i pisał dalej: Crac[oviensem] parte ex altera" itd.

Karty dwie, str. 63 - 66, są puste. Na str. 67 - 70 spisanych jest szereg krótkich zapisek p.t. „Summaria ex vi commissionis apostolice", utrwalających poprzez szereg terminów sądowych czynności procesowe sprawy zleconej przez Stolice. apostolską. Nie przedstawiają one interesu naukowego.

Poniżej publikujemy teksty dotąd nigdzie nie drukowane, a omówione wyżej pod 2), 3) i 4).

2.

[p. 25] Missa contra scismaticos habetur in hunc modum.

In primis dicantur septem psalmi cum letaniis, deinde Introitus ad missam: Miserere mei Domine quere feria secunda post Iudica me Deus, collecta Invictissime vel A cunctis, epistola Confortamini in Domino, graduale Exurge Domine, feria tercia post Letare, evangelium Attendite a falsis prophetis, offertorium Domine in auxilium, feria secunda ante Oculi, post Sed libera nos a malo legatur psalmus Letatus sum vel Fiat pax in virtute tua et abundantia in etc. Domine exaudi etc. Et clamor etc. Ecclesie tue quesumus Domine preces placatus admitte, ut destructis adversitatibus et erroribus universis secura tibi serviat libertate; Hostium nostrorum quesumus Domine elide superbiam 
et eorum contumaciam per sanctum angelum tuum dextera tue virtutis prosterne; Deus a quo sancta desideria etc., comunio Ne tradideris feria sexta ante Domine ne longe. Completorium ut supra circa collectas. Post missam cantetur antiphona Media vita vel Salve Regina. Ineffabilem misericordiam tuam nobis quesumus Domine clementer ostende, ut simul nos et a peccatis omnibus [p. 26] exuas et a penis, quas pro his meremur, eripias. Adesto quesumus Domine supplicationibus nostris et viam famulorum tuorum in salutis tue prosperitate dispone, ut inter omnes die ac nocte varietates tue semper misericordie protegantur auxilio. Omnipotens et misericors Deus, qui subvenis in periculis et necessitatibus laborantibus, maiestatem tuam suppliciter exoramus, ut mittere digneris sanctum angelum tuum, qui famulos tuos in angustiis et necessitatibus laborantes consolationibus attollat, quibus et de presenti consequantur auxilium et eterna remedia comprehendant, per Christum, Dicatur psalmus Sepe expugnaverunt me, versus Salvos fac servos etc. Ecclesie tue quesumus Domine preces placatus admitte, ut supra etc.

3.

[p. 27] Forma inquisitionis in visitatione archidiaconi in parrochiis.

Fratres, nos sumus missi per dominum nostrum episcopum et eius capitulum omnibus sibi commissis in salutem. Et est intentionis predicti domini episcopi et suorum a peccata evellere et virtutes plantare in cordibus Christi fidelium; et [quia est]b opus misericordie et magnum apud Deum meritum proximum ab errore revacare, ut vir impius derelinquat suam viam et vir iniquus cogitationes suas; ideo ne et vos, qui vestra bona fama deferente magis honesti et senes estis deputati in ista parrochia, ex aliqua criminis taciturnitate forte tamquam $c$ ex quodam consensu videamini peccata approbare, dicetis meram veritatem, quam scitis et de qua interrogati fueritis de omnibus excessibus et peccatis, que obviant saluti animarum, commissis in ista parochia vel alibi ubicumque in isto episcopatu, que ad vos pervenerint ex visu, auditu vel fama vel quomodocunque, pro illo divinam retributionem expectaturi. Sed quia testis, qui veritatem, quam novit, occultat et etiam is, qui mendacium dicit, [p. 28] reus est, primus, quia

\footnotetext{
a sanctorum $m s . ;$

b brak $m s$.

c tamen ms.;
} 
prodesse non wit, secundus, quia nocere desiderat, sancti patres decreverunt iuramenta esse exigenda $a b$ his, qui ut testes interrogati dicere veritatem debent, Ergo iurabitis sub hac forma et quivis seorsum: Ego iuro ad Sanctorum Dei reliquias; quod quecumque novi aut audivi, que contra voluntatem Dei et totam christianitatem in ista parrochia facta sunt, aut etiam in aliis vicinis parrochiis, quod ea nec propter parentelam nec propter amorem nec propter timorem nec propter precium nullatenus celabo episcopo meo aut eius misso seu missis, sed interrogatus veritatem dicam, quam scio, sic me Deus adiuvet et iste Sanctorum reliquie.

Si vero viderint presentatos [per] d parrochianos senes, grandevos, honestos, bone fame, tunc pretermisso iuramento, nisi quod eis insinuetur, qualiter deberent iurare, si non essent tam honeste persone, sic ad inquisitionem procedetur.

Quoniam pax est omnium et omnibus ultima, mediante qua etiam omnes homines christiani sunt salutandi, proinde ultimum est inquirere, si aliqui hominum inter se [p. 29] haberent iram inveteratam cum affectu vindicte.

Item, an per negligentiam aliqui homines neglecti fuerint in sacramentorum perceptione, maxime tempore infirmitatis vel mortis, aut decesserint sine confessione aut sine baptismo, et ex quorum negligentia hoc factum est.

Item, si aliqui plebani aut sacerdotes manifestaverunt confessionem sibi confitentium verbo, signo vel nutu vel quocunque alio modo.

Item, si aliqui sacerdotes celebraverunt missam aut celebrant horis canonicis pretermissis.

Item, si aliqui plebani alienos parrochianos suscipiunt ad missas in contemptum aliorum plebanorum et absque eorum licentia, maxime in diebus dominicis et festivitatibus magnis, aut ad sacramenta aut ad alia iura parrochialia vel ad ecclesiasticam sepulturam.

Item, si qui sacerdotes negligunt celebrare populo saltem in festivitatibus et in diebus dominicis aut aliis temporibus, quibus de consuetudine fuerit celebrandum.

Item, si aliqui sacerdotes in loco interdicto [p. 30] aut coram excommunicato aut suspenso celebraverunt ante absolutionem.

Item, si qui sacerdotes vel clerici non viatores ingrediuntur seu visitant tabernas ad bibendum cum aliis potatoribus vel ad comedendum.

Item, si qui clerici per se teneant vel regant tabernas, aliis potum vendendo.

Item, si qui clerici aut sacerdotes consueverunte inebriari sepe.

d brak ms.;

e tu $w$ ms następuje przekreślone: se 
Item, si qui sacerdotes longo tempore omiserunt celebrare et ex qua causa.

Item, si est et utrum est aliquis defectus in ornamentis et libris ecclesie et ex quorum culpa talis negligentia proveniat et visitatores hec actualiter inspiciant.

Item, si viderint ecclesie minantem ruinam, discoopertam, destructam vel cimiterium non vallatum, sepitum, interrogent, ex quorum culpa talis negligentia proveniat.

Item, utrum Corpus Christi et alia sacramenta sub bonis clausuris caute custodiunt tam a muribus quam a sacrilegis. [p. 31]

Item, si qui teneant ecclesias parrochiales in diocesi, ad quas non sunt per episcopum per collationem canonicam admissi aut legitime instituti.

Item, si qui a patronis receperunt beneficia cum diminutione proventuum aut negligunt iura ecclesie defendere.

Item, si qui beneficia sunt adepti symoniace.

Item, si qui denegant sacramenta peten[tibus], nisi solvant pecunias.

Item, si qui celebraverunt coram f-publice excommunicatis et-g eos admiserunt ad divina, preterquam ad sermonem.

Item, si fama sit de aliquo sacerdote aut clerico, qui teneant aliquam concubinam aut mulierem suspectam in domo vel extra domum.

Item, si quis sacerdos vel clericus ludo alearum seu taxillorum aut aliis ludis illicitis frequenter intendunt.

Item, si qui celebraverunt non ieiuni aut in ebrietate, per somnum non digesti vel plures missas uno die celebrarunt, excepto in Nativitate Domini, et que causa. [p. 32 ].

Item, si qui sacerdotes absolvunt a peccatis vel a sentenciis, a quibus absolvere non possunt preter auctoritatem Sedis apostolice aut episcopi.

Item, utrum aliqui sunt sepulti in ecclesia vel cimiterio, qui decesserunt in notorio mortali peccato aut in excommunicacione aut qui rectam fidem katholicam non habuerunt vel non tenuerunt aut manifesti usurarii, vel qui adminus semel in anno non sunt confessi aut sacram çommunionem non receperunt.

Item, si qui sacerdotes aliquos nominatim excommunicant propria auctoritate, non premissa monitione.

Item, si qui sacerdotes omiserunt sive omittunt denunciare excommunicatos, suspensos et interdictos, prout a prelatis suis habuerunt in mandatis.

Item, si qui clerici per alios ad ordines presentati suis presentatoribus promiserunt aut iuraverunt, quod eos super provisione sua non inquietabunt.

f-g excommunicatis et publice ms.; 
Item, si qui sacerdotes super incertis $\mathrm{h}$ debitis vel aliis male adquisitis, de quibus nescitur, cui restitui debeant, confitentes absque licentia episcopi speciali, ad quem de iure [p. 33] pertinet talia disponere, disposuerunt.

Item, si qui beneficiati se diu absentent a suis beneficiis absque licentia episcopi Pozn[aniensis].

Item, si qui clerici in sacris ordinibus constituti immisceant se negociis secularibus ordini suo non congruentibus vel si qui comam nutriant vel alias incongrue incedant absque habitu vel tonsura clericali.

Item, si qui plebani recipiunt vicarios aut presbiteros ignotos, de quorum conversatione non constet, et utrum sint in presbiteros ordinati et maxime si tales receperint absque licentia episcopi vel auctoritatem habentis.

Item, si qui plebani alienaverunt de rebus ecclesiarum suarum.

Item, si qui clerici celebrent in ecclesia sua vel oratorio effusione sanguinis vel modo alio execrato vel sepeliunt in cimiterio similiter execrato, antequam episcopali reconciliatione mundetur.

Item, si qui sunt, qui teneant aliquid iniuste de bonis ac iuribus mense episcopalis.

Item, si qui sunt obligati aliquibus i debitis ipsi episcopo vel mense sue.

Item, si qui vacan[te] aliquo beneficio vel ecclesia [p. 34] res sacerdotis derelictas aliquas receperunt et consumpserunt vel inter se diviserunt.

Item, si aliqui plebani decimas mense episcopalis iniuste occupant.

Item, si aliqua bona seu agri sunt extirpata, de quibus non datur decima episcopo.

Item, si aliqui laici retinent aliquas decimas mense episcopalis vel aliarum ecclesiarum seu beneficiorum, ut non solvant eas.

Item, si qui pulsis rusticis de agris ab eisdem nolunt solvere declmam.

Item si omnes, ad quos spectat decimare, nobiles et ignobiles, integre decimant.

Item, si plebanus vel alius loco sui sepe predicet verbum Dei in ecclesia.

Item, utrum sacerdotes concedunt indiscretas indulgentias ad decipien[dum] homines.

Item, si sacerdotes exponunt populo in sermonibus capitulum: "Omnis utriusque sexus", 1 id est, ut quilibet parrochianus in sua par-

$\mathrm{h}$ interdictis $m s$;

i tu $w$ ms. następuje przekrestone: iuribus.;

1 c. $12 \mathrm{X}$, De poenitentiis et remissionibus $V .38$. 
rochia adminus semel in anno proprio confiteatur sacerdoti et alia percipiat sacramenta.

Item, si quis episcopo suo verbis aut factis $[p .35]$ seu nutibus infidelis extiterit.

Item si qui domini seu parrochiani sine confessione permanserint per annum integrum vel per plures similiter absque communione.

Item, si qui sunt commanentes tanquam coniuges, qui non sunt in legitimo matrimonio constituti vel qui a suis coniugibus profugerunt.

Item, si qui sunt in gradu subdyaconatus vel ultra et stant cum mulieribus tanquam coniugati legitime.

Item, si qui coniuges nolunt simul manere et que causa.

Item, si qui superduxerunt alias uxores habentes primas uxores vel e converso primos maritos.

Item, si qui coniuges simul male vivunt puta in contentionibus et rixis illicitis.

Item, si qui alias uxores duxerunt, antequam certificati fuerant de morte uxoris sue vel antequam auctoritate episcopi fuerunt iudicio Ecclesie separati, similiter e converso de mulieribus.

Item, si qui contraxerunt sponsalia vel matrimonia clandestine seu occulte absque solemnitate plebani vel vicarii sui, id est sine bannis. [p. 36 ].

Item, si qui sunt adulteri manifesti.

Item, si qui incestuosi, ut puta, ubi consanguineus cum consanguinea vel affinis cum affini vel compater cum compatrissa sua vel sua filia spirituali carnale commercium habuerunt vel se illicite matrimonio copulaverunt.

Item idem intelligendum de confirmatione, ut puta inter confirmatum et illum, qui eum tenet ad confirmationem, aut eundem confirmatum et tenentem filios et filias uxorem ante carnaliter cognitam.

Item, si qui sunt heretici vel de sacramentis Ecclesie male sentientes.

Item, si qui invocent demones vel credant vel colunt plures quam unum Deum verum, qui omnia creavit, aut si qui adorent seu pro deo colunt aves vel arbores vel alias creaturas.

Item, si que sunt incantatrices, ut puta herbas foden[tes], appendicula ad colla facien[tes] wlgariter $n$ a w a $\mathrm{n}$ y vel manus inspicien[tes], ceram vel plumbum liquefactam fundentes, in ignem, aves, aquam inspicientes et ex eis futura predicen[tes], et si aliqui pro talibus habeant recursum ad eas. [p. 37].

Item, si qui occulta et suspecta conventicula inter se habuerint, ex quibus oriatur suspicio contra fidem.

Item, si qui Iudei aut pagani baptisati ritum infidelium reassumpserunt. 
Item, si qui sunt exercentes usuras vel recipiunt possessiones aliquas, ut puta villas, allodia, mansos in pignus vel in abligationem et fructus ac redditus [quos] $j$ in medio tempore ab eisdem ultra labores et expensas recipiunt, non computent in sortem nee permittant per eosdem redditus $\mathrm{k}$ debitum extenuari.

Item, si qui de lucro usurario usuram recipiunt.

Item, si qui colorante sub titulo vendicion[is] usuras exerceant, ut tempore medio de fructibus rei vendite recipiant. Nam licet ille con_ tractus emptio vel vendicio appelletur, sub dolo tamen est vera impignoratio ad lucrum usurarium capiendum.

Item, si qui recusant vendere pro parata pecunia sed potius [dant] 1. ad longiora tempora propter maiorem pecuniam recipiendam.

Item, si qui percusserunt vel captivaverunt clericos ordinatos vel personas religiosas vel eos rebus spoliaverunt. [p. 38].

Item, si qui laici receperunt oblationes sacerdotibus oblatas.

Item, si qui violaverunt libertatem ecclesiasticam, ut puta, si fu. gientem in cimiterium vel ecclesiam offenderunt seu per captivitatem eduxerunt.

Item, si qui rapuerunt aliqua de ecclesia vel dote ecclesie.

Item, si qui effregerunt aut alias violaverunt ecclesias vel cimiterium.

Item, si qui incendarii, qui domos vel horrea vel alias res aliorum incenderunt vel ad hoc dederunt consilium vel iuvamen.

Item, si qui periurium commiserunt vel fuerunt falsi testes.

Item, si qui fuerunt homicide, qui non satisfecerunt proximis occisorum neque absolutionem obtinuerunt.

Item, si qui viri vel mulieres per culpam suam aut negligentiam oppresserunt pueros aut occasionem morti eorum dederunt et confessi non sunt.

Item, si qui magni peccatores et maxime penitentiam publicam agere neglexerunt.

Item, si qui testamentum factum ad ecclesiam vel ad alia pia loca non impleverunt [p. 39] seu neglexerunt adimplere.

Item, si qui coegerunt aliquos excommunicatos absolvi vel interdictum relaxari per vim vel per metum.

Item, si excommunicati vel alii, quibus est ecclesiastica sepultura interdicta, in ecclesia vel in cimiterio sunt sepulti.

Item, si qui sunt falsarii litterarum vel sigillorum vel etiam monetarum, ponderis, ulne vel cuiuscunque mensure.

\footnotetext{
j brak w $m s . ;$

k. redditum ms.;

1 brak $w$ ms.;
} 
1tem, si qui consules vel aliqui potestatem haben[tes] faciunt statuta contra clerum aut contra iura ecclesiastica.

Item, si qui iudices vel consules requisiti neglexerunt viduis et orphanis iusticiam exhibere.

Item, si qui sunt spoliatores viduarum, pauperum aut eorum oppressores.

Item, si qui prohibebant vel impediverunt causas, que ad ecclesiasticum iudicium pertinent, deferri et tractari coram suo iudice ecclesiastico vel querimonias coram ipso proponi.

Item, si qui laici violenter sepelierunt in cimiterio vel in ecclesia corpora excommunicatorum, interdictorum aut in manifesto peccato decedentium. [p. 40].

Item, si qui plebani sint suis prelatis inobedientes ac rebelles.

Item, si qui non celebrant festivitates aut violaverunt ieiunia $a b$ ecclesia precepta.

Item, si qui laici trahunt [clericos] $\mathrm{m}$ ad iudicium seculare.

Item, si qui preter magnam necessitatem baptisant pueros extra ecclesiam in privatis domibus sive locis.

ltem, si qui negligunt venire diebus dominicis et festivis ad missas vel ad sermones suarum propriarum parrochiarum.

Item, si qui parrochiani tempore missarum vel sermonum exerceant risus vel fabulationes inutiles.

Item, si sciunt Pater noster, Ave Maria et Symbolum et utrum plebani in festivitatibus predicta pronuncient per se vel per alios Polonis $\mathbf{n}$ in polonico, Theutunis o in theutunico.

Item, si qui contemnant confirmationem accipere in fronte.

Item, si clerici vel laici aliqua enormia fecerint, de quibus scandalum sit exortum.

Item de aliis specialibus casibus vel excessibus clericorum vel laicorum inquiretur [p. 41] ulterius, prout in qualibet parrochia fuerit op[p]ortunum.

Item interrogetur sacerdos de defectibus ecclesie vel parrochie et visitatores videant litteras sue provisionis, institutionis et formatas clericorum.

Item, si quis clericus alterius diocesis ingesserit se de ordinibus recipien[dis] ab alio episcopo absque sui proprii episcopi licentia vel litteris dimissoriis et hoc tacuerunt ordinare.

Item, si aliquis illegitime natus vel irregularis ex tacito absque dispensatione debita se fecerit ordinare.

Item precipiatur, ut in qualibet ecclesia sacramentum sacratissime Eucaristie de octava in octavam renovetur in pane recenti etc.

$\mathrm{m} \mathrm{brak} w \mathrm{~ms}$;

n Polonos ms.;

o Theutunos ms.; 
4.

[p. 42] Responsiones prelatorum et cleri Cracovien[sis] diocesis ad articulos dominorum nobilium r[egni] P[olonie] nuper presentatos.

Et primo ad primum articulum continentem in effectu, Quod dum heres unum vel plures kmethones deponit et ibidem araturas facit, decima manipularis de illo agro aut census, qui solvebatur per kmethonem, ab herede non requiretur, Respondetur, quod cum iste ager ad solvendum alias beneficiato cuicunque sive sit episcopus vel inferior prelatus vel clericus habens prebendam altare vel parochialem ecclesiam sit obligatus ex privilegio fundationis aut alio iure legitimo, nullam habent iniuriam, si solvunt, ad quod iure vel privilegio stringuntur. Nam res transit cum onere suo sicut hereditas aut ager, que tenetur ad aliquam servitutem, et ita aret nobilis vel etiam spiritualis, nichilominus tenetur ad solvendum, alioquin esset iniuria, ut propter nobilitatem alicuius ecclesia in censu vel decima damnum pateretur.

Ad secundum, qui continet in effectu, Quod nobiles volunt dare decimas, cui placet, Respondetur, quod uti tali libertate cum gravi damno ecclesie non possunt sine mortali peccato.

Et primo ex eo, quia beneficia per ipsos aut episcopos in talibus decimis fundata perirent;

Secundo, quia sicut parochiales ecclesie talia beneficia per ipsos predecessores fundata anullarentur, sic et illa, que per ipsos vel ipsorum successores fundarentur, [p. 43] nunquam robur haberent, sed processu temporis transirent in nichilum. Ex quo patet, quod ista libertas non tantum nocet ecclesie, ymo et milicie, volumus tamen istam prerogativam dare milicie: Primo, ut decima post araturas depositorum kmethorum non conducatur per heredem ibidem arantem, sed per illum, ad quem spectat decima, secundo, quod inter capetia non sit electio, que sit melior, sed capete decimum, quod venit ex ordine.

Tercio, quod decima canapi per eos non solvatur de eisdem agris ipseque recipiens decimam teneatur orare pro salute dominorum nobilium eandem decimam solventium et suorum predecessorum.

Quarto, si decima alicui ecclesie vel prebende aut altari est per papam vel episcopum, qui a Deo potestatem recepit, assignata fuerit et appropriata, non sine peccato mortali potest ab una ecclesia abstrahi et alteri dari, unum altare nudari et aliud indui. Si autem non fuit, nec est assignata sed remansit vaga hucusque, quod sine peccato non erat, placeat accedere ad episcopos, ut pro devotione dominorum nobilium in talibus decimis parochiales ecclesie, altaria vel prebende erigantur, omnes enim decime ab initio sunt episcoporum, quorum est 
easdem decimas, prout honori congruit divino et devotioni fidelium, ordinare. Ad seculares autem pertinet devotionem suam vel affectum ad hoc faciendum exponere. Dignentur ergo vestre nobilitates huic morbo inveterato occurrere. Nam istud repugnat iuri divino et humano, nec videtur habere rationem fundatam sed meram voluntatem. [p. 44]

Ad tertium, qui continet in effectu, Quod stramina, que remanent ex decima de hereditate, in qua collecta est decima, educi non deberent.

Respondetur, quod qui emit decimam, emit granum et stramina, artare ergo emptorem ad hoc, quod relinquat simpliciter stramina, non est sine offensa proximi et ita legis divine aut quad vendat, ibi non est sine iniuria, qua artatur emptor, ut vendat remissius et beneficiatus propter illibertatem huius modi non de facili potest invenire emptorem, nisi cum damno. Nullus autem debet ditari cum alterius detrimento. Volumus tamen, quod stramina apud hospitem, circa quem decima locatur, qui ipsam decimam custodit, sepe circumdat et acervos facit, [remaneant?] a.

Ad quartum, qui continet in effectu, Quod per commissiones extra Regnum citantur, Respondetur, quod episcopi extra Regnum nunquam committunt causas sed papa dat commissionem, cuius potestatem concludere vel manum suam accurtare non valemus, quantum est autem in nostris diocesibus, volumus providere, ut huiusmodi vexationibus occurratur.

Ad quintum in effectu continentem, Quod dum secularis citans secularem ad seculare iudicium causas perdens nepoti vel amico cedit, qui trahit ad spirituale iudicium, Respondetur, quod volumus per constitutionem vel mandatum providere, quod dum et quando legitime res fudicata coram iudice ecclesiastico fuerit allegata, [p. 45] debebit omnino ad seculare iudicium reverti. Et item si fuerit secularis causa, quod ad forum seculare revertatur.

Ad sextum et septimum de decimatoribus, qui signare capetia decimata, nisi sint muneribus subarrati, recusant vel prolongant nec decimare volunt, nisi omnes messuerint, providere volumus, quod decimatores, si necesse fuerit, iurent in manibus dominorum suorum fideliter decimare, nec fraudem in talibus adhibere, tempus autem aptum ad decimandum limitetur, sicut in diocesi Cracoviensi est consuetum, non est enim sine offensa Dei, ut propter unum capete decem pereant et fideles in suis laboribus frustrentur. Equum est etiam et providendum, quod spirituales non de uno decimatore, ubi plures sunt decime, sint contenti, sed plures dirigantur ad decimandum tempestive, ne populus negligatur, quod providebitur per mandatum. Fiat ta-

a brak rkp. 
men, quod kmethones in parte illa, ubi metere inceperunt, compleant, ne furta modicis decimatis committantur.

Ad octavum, quod decimatores nolunt ordinarie recipere, sed simul in uno cumulo, ubi meliores sunt fruges. Respondetur, quod iniuriosum est meliora tollere et in aliis nolle recipere, ymo qualia in quacumque parte proveniunt, recipere tenetur. Super quo necesse est, ut provideatur, et parati sumus contra hoc providere.

Ad nonum, Quod moniciones dantur cum sententia personis non citatis. Respondetur, quod ubi manifesta est violentia vel notoria offensa aut si quis se libere coram [p. 46] officiali vel episcopo obligavit, citari non indiget. In aliis autem ne dentur monitiones volumus iudicibus inhibere. Volumus tamen ob complacentiam vestrarum nobilitatum, (quod) b citatio premittatur ad dicendum causam racionabilem, quare pro manifesta offensa et violentia notoria excommunicari non debeat.

Ad decimum, qui continet, quod spirituales volunt habere medietatem missalium cum cumulo et superhabundantia et medietatem equaliter mensuratam. Respondetur, quod circa hos servetur consuetudo regionis vel diocesis aut sicut solvit suo domino, ita solvat spiritualibus.

Ad undecimum de impetrantibus ecclesias nobilium Respondetur, quod de iure non habent locum impetrantes ubi ius patronatus est nobilium. Sed si forte de ecclesiis non disponunt presentando infra tempus debitum, tunc papa se intromittit iure devoluto, quia tunc negligentie sue poterint imputare.

Ad duodecimum de bannis nobilium Respondetur, quod nostrum non est ius sacrorum canonum, quod penam suspensionis sacerdotibus infert, tollere. Sed tamen patientes sustinebimus, quod banna non fiant, ubi solennis tractatus inter nobiles precessit, nec fuit consuetudo, quod banna inter nobiles premitti deberent. Inter populares autem omnino banna premittantur, quoniam ad hoc sunt banna constituta, ut impedimenta evitarentur, que ex consanguinitate, compaternitate, affinitate, incestu et adulterio eveniunt, vel contraxit [p. 47] cum alia vel machinatus est in mortem, propter quod etiam inter nobiles temporibus nostris evenerunt talia impedimenta.

Ad tredecimum de illis, qui recedunt de scolis et exercent mercantias aut alias turbantes homines nec tonsuram deferentes et nichilominus gaudere privilegio clericali volentes. Volumus providere, ut trina monitio premittatur, cum certo dierum intervallo, alioquin non gaudebunt privilegio clericali, nec episcopus cum suis officialibus pro talibus se interponant.

b brak $r k p$. 
Ad quartum decimum, qui continet in effectu, Quod ubi nobilis cum spirituali habent simul unam villam et secularis iniuriam passus citat ad seculare iudicium, in causa, que pertinet ad iudicem secularem, nichilominus spiritualis revocat ad forum spirituale, Respondetur, quod secularis potest allegare litis pendentiam qua probata remitti debebit et ipse spiritualis in expensis seculari condemnari. Quod intelligimus sic, quod semper, ubi secularis est causa debebit remittti ad forum seculare, spiritualis autem causa in foro spirituali tractari.

Quindecimus articulus est singularis et singulariter per episcopum proprium discutiendus nec tangit diocesim Cracoviensem.

Ad sedecimum, Quod spirituales volunt decimam signare, priusquam ortulani sua recipiant deservita, Respondetur, quod cum tam ille, cuius ager est, quam ortulanus, qui laborat, simul et in solidum [p. 48 ad solvendum decimam teneantur, prius debet dari decima, quam fieri aliqua signatura et pnius Deo quam homini est solvend(um) tanquam digniori. Et etiam hoc fit per Dei gratiam in diocesi Cracoviensi:

Ad decimum septimum de molendino aquatico et ventilabrato quod una mensura annuatim requiritur, non est iniuria, cum de divino iure decima de iustis laboribus debeatur, licet in regno nostro non sit usus, ut de artificio vel milicia, venatione aut similibus decima persolvatur. Non tangit diocesim Cracoviensem.

Ad decimum octavum de beneficiat, qui volunt habere pecunias pro maldratis et si debiles fruges fuerint, volunt habere meliores et in propriis quartalibus volunt mensurare, Respondetur, quod debent esse contenti de maldratis nec cogi debent kmethones ard dandum pecunias, nam dant quod tenentur, similiter debent fruges recipere, quales proveniunt, dummodo fraus non intervenerit, de mensura vero propria non refert, si equalis est aliis, alioquin, si est suspecta, ad communem scilicet oppidi vicinioris forum commune habentis, si est ibi, recurratur aut alie vicinorum apportentur, ut sit equalitas inter illas, non tangit etiam diocesim Cracoviensem.

Ad decimum nonum de confessoribus, qui in extremis inducunt infirmos, ut bona sua ipsis legarent. Respondetur, [p. 49] quod provisum est contra tales confessores per ius sacrum, quia tales sacerdotes ipso facto sunt excommunicati qui non salutem hominum, sed utilitatem propriam querunt. Et qui tales fuerint in talibus excedentes, episcopis dicantur. Legare vero pro anima sua rationabiliter nullus potest prohiberi, sed circumvenire infirmum sacerdos non debet.

Ad vicesimum de clericis contra prohibitionem nobilium in medio noctis ambulantibus Respondetur, quod ipsorum episcopis perferantur, ut. secundum demerita puniantur.

Ad vicesimum primum, si quis clericus in adulterio captus officiali presentatur post triduum statim dimittitur, volumus diligentiam habe- 
re, ut clerici adulteri et scelerati acriter puniantur, et demandare, ne dimittantur de facili, sed aut perpetuis carceribus mancipentur vel tandiu reclusi maneant, ut pro peccato agant penitentiam condignam, ut ceteri terreantur.

II.

Rękopis Biblioteki Uniwersytetu Warszawskiego nr inw. 459.

Przeglądając kartotekę mikrofilmów Stacji Mikrofilmowej Biblioteki Narodowej $w$ Warszawie, natrafilem na pozycje, która wzbudziła moje zainteresowanie. Wśród rękopisów Biblioteki Uniwersytetu Warszawskiego, pochodzących z XVI wieku, wykazana jest pozycja: „Statuta Proulincie Gnesnensis antiqua revisa diligenter et emendata. Statuta nova... MDXXVII. 40. - K. 56v - 58: zapiski rękopiŝmienne z XVI w. zawierające statuty diecezji poznańskiej z lat 1462, 1466, 1486, 1506. - Łac. W. XVI, k. 128, $22 \times 16 \mathrm{~cm}$. - B.U.W. $\mathrm{nr}$ inw. 459. Mikrofilm nr 13299". Zainteresowanie moje wzrosło, gdy w Oddziale rękopisów Biblioteki U.W. wręczono mi egzemplarz dobrze znanego mi wydania gnieźnieńskich konstytucji prowincjonalnych tzw. Zbioru Easkiego, wydrukowanego u Scharffenbergera w Krakowie w 1527 r., zatytułowanego: Statuta Prouincie Gnesnen. Antiqua Reuisa diligenter et Emendata. ${ }^{1}$ Otóż co się okazało: na karcie $\mathrm{O}_{4} \mathrm{~V}(=56 \mathrm{v})$ i na następnej pustej, nie sygnowanej karcie (k. 57) wprawna ręka z połowy XVI w. wpisala szereg tekstów jednym ciąiem, tworząc dość zwarty zestaw fragmentów o treści prawniczej. Oto one:

De grege pascendo [na marg.] Anno Domini 1462 die vero Mercuri ultima menisis iunii in capitulo generali pro festo beatorum Petri et Pauli apostolorum celebrato. Ibidem domini decreverunt, quod tam kmetones pascen[tes] gregem wlgariter wolowska per se, quam eciam pastor gregis communis ville, in qua est ecclesia parrochialis, plebano absque aliqua dacione et contribucione per kmetones solvi consueta singula peccora et pecudes, quantumcunque habuerit, pasci tenebuntur, Ita tamen, quod plebanus a pastore communis gregis et ipsius familia nihil iuris parrochialis recipiat, sed in recompendium vicissitudinis

1 Estreicher, Bibliografia polska T. 29, 247-249 daje obszerny i dokladny opis tego starodruku. 
quemadmodum plebanus in administrandis divinis eidem servit pastori, ita et ille plebano in temporalibus deserviat.

Avisare decimacionem [na marg.]. Anno Domini 1466 die Veneris XII novembris in capitulo generali pro festo sancti Martini celebrato. Ibidem reverendissimus dominus Andreas episcopus et domini decreverunt perpetuo observandum, quod omnes nobiles tenentur avisare plebanos aut eorum factores super decimacionem decimarum post agros et culturas eorum prediales et nonnisi in presencia plebanorum aut factorum eorumdem post avisacionem huiusmodi audeant decimare.

Missalia (de) desertis. [na marg.] Anno Domini 1486 die ultima iunii in capitulo generali pro festo beatorum Petri et Pauli celebrato. Ibidem reverendissimus in Christo pater dominus Uriel episcopus de consensu tocius capituli decrevit et sentenciavit, quod de mansis desertis, per quemcumque arabuntur sive per nobiles sive per kmetones, missalia solvi debent prout tunc debebant, quando in eis kmetones personaliter residebant.

Anno Domini 1506 feria secunda post dominicam Misericordiam, que fuit 27 mensis aprilis, per reverendissimum dominum Joannem Lubranskj episcopum in sinodo diocesana protunc Posn[anie] celebrata.

Arendan[tes] laicis. [ $\mathrm{Na}$ marg.] Nullus plebanus audeat ecclesias vel proventus ecclesie locare patronis vel secularibus personis, nam in tali locacione ipsi heredes appropriant sibi bona ecclesie, alia anihilant, et ut eis pociantur, non permittunt plebanos residere. [fol. nlb. $=\mathrm{k} .57$ ].

Item ut ad capsas seu statuas, in quibus servantur peccunie ecclesiarum, tres claves habeant, quarum una sit apud plebanum, aliam economi seu victrici et terciam patroni teneant et unus sine altero in dispensacionem peccunie sé non intromittat.

Item ne peccunias ecclesiarum dent in mutuum quibuscunque [c]ensum ab eis recipiendo, sapit enim talis recepcio usuram.

Item contractus si quos cum laicis facere volunt, ne cogantur solucionem apud secularem iudicem petere, faciant se ipsis contrahentibus in actis consistorii obligare et iurisdiccioni ecclesiastice subdere. Quoniam, si secus fecerint, cogentur apud eorum iudices solucionem petere.

Item metricas habeant contrahencium matrimonium et baptisatorum ac excommunicatorum.

Pyotrkouie anno Domini 1542 Petrus archiepiscopus Gnesnensis et Cracoviensis episcopus in sinodo Pyotrkouiensi.

De salariis vicariorum parrochialium.

Quia nonnulli rectores $><$ libere fore dimittenda.

Cause mere spirituales sunt hec. $><$ et res ecclesiasticas commissi.

Cause spiritualibus annexe et mixti fori sunt iurispatronatus et dotis post divorcium restituende et repetende. 
Cause mixti fori sunt.

Testamentorum et ultimarum voluntatum $><$ irremissibiliter puniatur.

Contra insordescentes in censuris ibidem.

Et quia ex contemtu censurarum $><$ ne quavis facili causa ad fulminacionem censurarum presertim interdicti procedatur.

De tempore sacre communionis.

Eugenius papa quartus in quadam decretali habita in consistorio. Fidedigna relacione percepimus in civitate Licij non parvam per hec tempora exaitatam fuisse commocionem $><$ Datum Rome etc.

Jak widzimy ekscerpowany materiał obejmuje 3 grupy:

1. Dosłowne, $z$ drobnymi jedynie odmiankami, odpisy trzech zapisek $\mathrm{z}$ acta actorum kapituły poznańskiej z 30 czerwca $1462^{2}$, z 12 listopada $1466^{3}$ i z 30 czerwca $1486^{4}$. Wszystkie trzy zapiski dotyczą aktualnych zagadnień gospodarczych, tj. świadczeń na rzecz instytucji kościelnych.

2. Druga grupa obejmuje wyciągi ze statutów synodu diecezjalnego poznańskiego, odprawionego przez biskupa Jana Lubrańskiego w dniu 26 i 27 kwietnia 1506 r. O fakcie odbycia się tego synodu i o niektórych sprawach, będących przedmiotem jego obrad, jak kontrybucja królewska oraz retaksacja beneficjów, posiadaliśmy już pewne, acz szczupłe wiadomości ${ }^{5}$. Na tej podstawie zaryzyk'owaliśmy swego czasu twierdzenie, że „uchwały tego synodu nie posiadały więc charakteru statutów, lecz jedynie uchwal administracyjnych. Tekst ich nie zachował się"6. Odnalezione obecnie fragmenty nie znanych dotąd statutów tego synodu świadczą więc, że $I^{0}$ na synodzie zapadły uchwały nie tylko administracyjne, lecz wydane zostały sta-

2 Ula nowski B., Acta capitulorum nec non iudiciorum ecclesiasticorum selecta, T. I (Monumenta Medii Aevi Historica T. 13) Kraków 1894, 107, nr 555.

3 Zapiska ta dotąd nie była publikowana.

4 U la now ski B., o.c., 143, nr 764 .

Nowacki J., Księga uposażen diecezji poznańskiej z roku 1510. Poznań 1950, 7-8; S a w i cki J., Concilia Poloniae T. 7 o.c., 51-53; Nowacki J., Zapiski historyczne z lat $1410-1530$ (z Ksiag Archiwum Archidiecezjalnego w Poznaniu). Studia Zródłoznawcze T. 3 Poznań 1958, 168.

6 Sawi cki J., Concilia Poloniae T. 7 o.c., 53. 
tuty synodalne $\mathrm{w}$ właściwym tego słowa znaczeniu; II0 publikowane tu fragmenty są jedynie częścią statutów, statuty właściwe musialy być zapewne znacznie obszerniejsze i zawierać uchwały zarówno $w$ przedmiocie kontrybucji, jak i retaksacji beneficjów i sporządzania inwentarzy; III0 statuty zapewne nie były drukowane, lecz starym sposobem rozsyłane po archidiakonatach i dekanatach $\mathrm{w}$ kopiach rękopiśmiennych; $\mathrm{IV}^{0}$ statuty te jeszcze $\mathrm{w}$ polowie XVI w. były w użyciu, skoro robiono $\mathrm{z}$ nich wyciągi dla podręcznego użytku.

O całości tych statutów trudno coś orzec. Znane nam fragmenty dotyczą $w$ większości administracji majątku kościelnego, a tylko ostatni dotyczy obowiązku plebanów prowadzenia ksiąg ślubów, chrztów oraz wykazów osób ekskomunikowanych.

Pierwszy $\mathrm{z}$ tych fragmentów krótko formułuje i ciekawie motywuje zakaz wydzierżawiania kościołów lub dochodów kościelnych patronom lub innym osobom świeckim, wyciągając właściwe wnioski z słynnej konstytucji Pawła II „Ambitiosae cupiditati" z 1 marca $1468 \mathrm{r.}^{7}$

Drugi fragment reguluje $\mathrm{w}$ ciekawy i oryginalny sposób sprawę administrowania, a raczej przechowywania pieniędzy kościelnych, na zasadzie zgodnego współdziałania trzech czynników: proboszcza, witrykuszów ${ }^{8}$ oraz patrona kościoła, podobnie, jak to już w XV w. unormowano w diecezji chełmskiej ${ }^{9}$.

Fragment trzeci zawiera postanowienie skierowane przeciwko praktyce kupna renty. Wyciaga skrajne konsekwencje $z$ licznych zakazów uprawiania lichwy, zawartych w ustawodawstwie powszechnym oraz statutach prowincjonalnych gnieźnieńskich.

Fragment czwarty, który o ile mogłem stwierdzić, nie ma precedensu $\mathrm{w}$ polskim ustawodawstwie partykularnym przed 1506 rokiem, nakazuje proboszezom wpisywać wszelkie umowy

7 Por. c. un, De rebus ecclesiae non alienandis, III, 4 in Extrav. comm.

8 O instýtucji witrykuszów patrz ks. Stefan Sołtyszewski, Geneza instytucji witrykusów $w$ polskim ustaworawstuie synodalnym. Prawo kanoniczne R. 2: 1959 nr 1/2, 425 i n., nr 3/4, 341.

9 Sawicki J., Concilia Poloniae T. 4, 165. 
$\mathrm{z}$ osobami świeckimi do alkt konsystorza, by mogący w przyszłości wybuchnąc spór sądowy znalazł się tym samym przed właściwym sędzią duchownym, a pleban nie był zmuszony szukać sprawiedliwości w sądzie świeckim.

Ostatni wreszcie fragment przypomina plebanom obowiązek prowadzenia metryk kościelnych oraz wykazów osób wykiętych. ${ }^{10}$

Omówione wyżej fragmenty dają wyobrażenie o na wskroś popularnym, praktycznym ujęciu statutów z 1506 roku i o ich aktualnej treści, dostrojonej do bieżących potrzeb duchowieństwa parafialnego.

3. Trzecia wreszcie grupa wypisów obejmuje kilka artykułów statutów synodu prowincjonalnego odprawionego w Piotrkowie w dniu 17 października 1542 r. i następnych. ${ }^{11}$ Są to zapewne wypisy $z$ drukowanego $\mathrm{w} 1544 \mathrm{r}$. wydania tych statutów.

Pierwszy fragment, to art. 46 ,De salariis vicariorum parochialium"12 zabraniający proboszczom obniżania uposażeń swoich wikariuszy i służby kościelnej.

Następne trzy fragmenty, to wyciąg z art. 18 „Causae mere spirituales" oraz cały art. 19 "Causae spirituali annexae"13, ustalające granice między kompetencją sądów duchownych, a świeckich.

Piąty fragment, to znów pełny art. 11 ,Statutum contra insordescentes". ${ }^{14}$

Ostatni fragment pod tytulem „De tempore sacre communionis", to dekretal papieża Eugeniusza IV z 8 lipca 1440 r. ${ }^{15}$ w sprawie okresu wielkanocnego.

10 Por. art [16] statutów przemyskich z 1415 r. (S a wi cki, Concilia Poloniae T. 8, 135) oraz art. 12 statutów krakowskich z $1459 \mathrm{r}$. (H e yzmann, Statuta synodalia episcoporum Cracoviensium XIV et XV saeculi w Star. Prawa Polsk. Pomn. T. 4 s. 112).

11 Statuty tego synodu przedrukował B. Ula now ski, Materialy do historii ustawodawstwa synodalnego $w$ Polsce $w$ w. XVI. Arch. Kom. Prawo kanoniczne R. 2: 1959 nr 1/2, 425 i n.; $\mathrm{nr} 3 / 4,341$.

12 Ula nowski B., Materiaty, o.c., 403 (79).

13 I b i d e m, 394-395 (70-71).

14 I bidem, 391 (67).

15 G a sparri, Codicis iuris canonici fontes, T. 1 (1947) s. $77 \mathrm{nr} 53$. 
Na tym kończy się zespół tekstów prawnych, wpisany jedną i tą samą ręką na pustych kartach starodruku, Wpisanie ich nastąpiło najpewniej po 1544 roku, t.j. po ukazaniu się drukowanego wydania statutów piotrkowskich z $1542 \mathrm{r}^{10}$

Egzemplarz tego starodruku interesująco się przedstawia $\mathrm{z}$ innego jeszcze powodu. Teksty synodów, zwłaszcza zaś tekst statutów wieluńsko-kaliskich z $1420 \mathrm{r}$., są bogato glosowane na marginesach. Glosy te pochodzą od innego pisarza, niżeli ten, który wpisal omówiony zespól tekstów prawnych. Rabią one wrażenie notatek marginesowych, $z$ odsyłaczami do prawa powszechnego i do literatury kanonistycznej, wykorzystywanych czy to $w$ praktyce kurialnej, czy to przy wykładach prawa kanonicznego. Nie znamy właściciela omawianego starodruku. Możemy jedynie przypuszczać, że należał on do któregoś $z$ uczonych prawników, zajętych $w$ administracji diecezji poznańskiej, mającego przeto dostęp i do ksiąg kapituły poznańskiej, a równocześnie wykładającego prawo kanoniczne w Akademii Lubrańskiego, zorganizowanej w 1519 roku.

III.

Rękopis Biblioteki Narodowej w Warszawie nr BOZ 822.

O synodzie prowincjonalnym, odprawionym przez arcybiskupa Jana Latalskiego w Piotrkowie w 1539 r. literatura nasza wspomina juz od dawna. Wymienia synod ten ks. F a bis z, ${ }^{1}$ podając streszczenie niektórych jego uchwał, za nim powtarza wiadomości te ks. Bukowski, ${ }^{2}$ krótko opisuje jego dzieje

16 Estreicher, Bibliografia polska T. 30 , s. 126.

1 Fabisz W., Wiadomość o synodach prowincjonalnych i diecezjalnych gnieźnieńskich i o prawach Kościoła Polskiego. Kępno 1861 s. 157.

2 Bukowski J., Dzieje Reformacji $w$ Polsce T. 1 Kraków 1883, 555. 
ks. Korytk ow ski3 w żywocie prymasa Latalskiego, wymienia go w swoim katalogu synodów ks. Stanisław Chodyńsk i podając, że Władysław Okęcki, profesor Szkoły Głównej w Warszawie posiadał podobno statuty tego synodu, od niego przejął te wiadomości ks. Ka k o w sk $\mathrm{i}^{5}$, rejestruje synod ten wreszcie ks. $\mathrm{K}$ al $\mathrm{w} \mathrm{a}^{6}$. Znane byly również niektóre fragmenty statutów tego synodu, przejęte do zbioru konstytucji synodalnych biskupa Stanisława Karnkowskiego, wydanego drukiem ${ }^{7}$ w 1579 roku. ${ }^{8}$ Są to następujące fragmenty:

1. W księdze I De officio archidiaconi (k. $18 \mathrm{v}-19)$ przedrukowany jest pod naglówkiem „Latalicii \& Gamrati” fragment: Cogant etiam $><$ disponere debebit. Jest to dosłowny, w kilku drobnych szczególach jedynie uzupelniony tekst art. 35 statutów synodu prowincjonalnego piotrkowskiego z 1542 r. ${ }^{9} \mathrm{Co}-$ prawda artykuł ten statutów z 1542 r. nie jest niczym innym, jak to niżej zobaczymy, jak tylko rozwiniętym i uzupełnionym

3 Korytkowski J., Arcybiskupi gnieźnieńscy, prymasowie i metropolici polscy od roku 1000 aż do roku 1821, Poznań T. 3, 1889, s. $69-70$.

4 Chodyński S., art. „Synody Kościola polskiego” w Enc. Kośeielnej Nowodworskiego T. 27 (1904), 404.

5 Kakowski A., Biskupa Stanisława Karnkowskiego zbiór konstytucji synodalnych. Włocławek 1912, 10, przyp. 19.

$6 \mathrm{Ka}$ a a P., Rys historyczny prowincjonalnego ustawodawstwa synodalnego $w$ Polsce przedrozbiorowej, w Księdze Pamiątkowej ku czci biskupa Mariana Leona Fulmana, cz. I Lublin 1939, 147.

7 CONSTITVTI- | ONES SYNODO- $\mid$ RVII, METROPOLITA- | NAE ECCLESTAE GNESNEN- | SIs, Prouincialium, tam vetustorum quam | recentiorum, vsque ad Annum Domini, IM. D. LXX VIII. | STVDIO ET OPERA | REVERENDISSIMI IN CHRISTO PA- | tris, Domini STANISLAI KARNKOVVSKI, Dei | gratia Episcopi Wladislauien \& Pomeraniae, colle- ctae, \& ad praescriptum sacrosancti Concilii Tri- | dentini, \& S. Sedis Apostolicae, correctae, \& | in vnum volumen redactae. [Tu winieta]. CRACOVIAE, | Andreas Petricouius impressit. Anno Do- $\mid$ mini,, 1579. in 40, k. tyt., k. 7 nib., k. 192 lb., k. 8 nlb. - Estreicher, Bibliografia polska, T. 30 s. 127-128.

$8 \mathrm{Na}$ fragmenty te wskazują Al. Ka kow ski, o: c. W tabl. I i III oraz K a $ł$ w a P., o.c., 147 przyp. 3.

9 Ulanowski B., Materialy do historii ustawodawstwa synodalnego $w$ Polsce $w$ w. XV. - Arch. Kom. Prawn. T. 1, 399-400. 
tekstem odpowiedniego artykułu statutów z 1539 r. ${ }^{10}$, nie mniej jednak ani formalnie, ani materialnie nie bylo podstawy do wiązania tego tekstu $\mathrm{w}$ Zbiorze Karnkowskiego $\mathrm{z}$ nazwiskiem Latalskiego.

2. W księdze I De maioritate et obedientia (k. $37 \mathrm{v})$ figuruje fragment pod nagłówkiem ,Ioannis Latalski \& Gamrati. Petricouiae, Anno Domini, 1539." Promiserunt etiam domini archie-piscopus><aliquo pacto impediendo. Jest to $w$ rzeczywistości dosłownie przejęty tekst odpowiedniego fragmentu ze statutów 1539 r., wszedł on do statutów z 1542 r., w których znalazł się $\mathrm{w}$ art. $24 \mathrm{~A}$ cohertione non provocandum ${ }^{11} \mathrm{w}$ szerszym związku, lecz Zbiór Karnkowskiego oparł się na brzmieniu tego fragmentu w redalkcji z 1539 r. Znów stwierdzamy, że inskrypcja Zbioru Karnkowskiego nie jest ścisła ${ }^{12}$.

3. W księdze I De procuratoribus (k. 38 v) Zbiór Karnkowskiego przedrukował fragment pod nagłówxkiem: „Ioannis Latalski Petricouiae, 1539". Decrevit etiam ut clerici $><$ in iure communi desuper expressis. Również i ten fragment przejęty jest do zbioru Karnkowskiego bezpośrednio ze statutów $1539 \mathrm{r}$. nie zaś ze statutów 1542 r., gdzie figuruje jako art. 34 Ne clerici in iudiciis secularibus. ${ }^{13}$ Karnkowski coprawda tekst ten nieco przerobil, może miał przed soba przy tym i wspomniany artykuł statutów z $1542 \mathrm{r}$., lecz porównanie tych trzech redakcji nie pozostawia żadnej wątpliwości, że wzorem dla Karnkowskiego był tekst statutów z 1539 r. Tym razem więc inskrypcja dana przez Karnkowskiego jest ścisła. ${ }^{14}$

Tyle wiedzieliśmy dotąd o statutach synodu Jana Latalskiego z 1539 r. Mało, jak na synod prowincjonalny w jkresie potęzniejącego ruchu reformacyjnego, mało jak na pierwszy synod

10 Zauważyl to już $\mathrm{K}$ a kow s ki A., o. c. tabl. I.

11 Ula now ski B., Materialy. o. c., 397.

12 K a k ow ski A., o. c. tabl. III dodaje tu uwagę: „Błąd w nadpisie. Powinno być: Ex syn. Petric. 1542". Widzimy, że na czymś wręcz przeciwnym polega tu nieścisłość.

13 U lanowski B., Materiaty, o. c., 399.

14 I tym razem myli się Kakowski A., o. c. tabl. II dodając uwagę: „Błąd w naglówku. Powinno być: Petri Gamrati 1542”. 
po burzliwych zajściach spod Lwowa w 1537 r. i po dwóch po nich następujących sejmach z 1538 i z 1538/39 roku.

Obecnie znamy już pełny tekst tych niezwykle ważnych i ciekawych statutów. Odnalazł go i pierwszą o nim podał wiadomość ks. dr Zdzisław M. S z mid t w swojej pracy doktorskiej o źródłach Zbioru Karnkowskiego ${ }^{15}$, przedłożonej w maszynopisie w 1954 roku Wydziałowi Teologii Katolickiej U. W., dając równocześnie opis rękopisu i streszczenie statutów w nim zawartych ${ }^{\mathbf{1 6}}$.

Rękopis Biblioteki Narodowej w Warszawie $\mathrm{nr}$ BOZ 822, ongiś Biblioteki Ordynacji Zamojskiej, to niedużego formatu rękopis papierowy in $4^{0}$, z XVI w., o rozmiarach $159 \times 207 \mathrm{~mm}$, liczący 16 kart, foliowanych (tylko karty nieparzyste) współczesną ręką XIX lub XX w. cyframi arabskimi. Oprawa rękopisu z początku XIX w. skórzana, dobrze zachowana, pośrodku. na przedniej, jak i na tylnej oprawie wytloczony w złocie herb Zamoyskich Jelita, na przedniej oprawie pod herbem inicjały S. O. Z. (Stanisław Ordynat Zamoyski), powyżej oraz poniżej herbu wytłoczone $\mathrm{w}$ zlocie po dwa splatające się wieńce laurowe, w środku napis „Vtraq. Civis".

Cały ten okternion stanowiący omawiany tu rękopis, tworzył kiedyś może część większej całości, zanim został z niej wypruty i osobno oprawiony. Nie jest to z całą pewnością ten odpis, o którym wspomina St. Chod yński, wskazująe rzekomego jego posiadacza.

Tekst statutów spisany jest wprawną ręką z polowy XVI w. Nosi tytu1: „Decreta Synodi Piothrcouien[sis] pro festo Ascensionis Domini Anno eiusde[m] 1539 celebratę", oraz podpis: „Mathias Lączkj Cancellarius R[everendissi]mi domini archipraesulis Gneznen[sis]". Tekst i podpis pochodzą od tego samego pisarza, jest przeto prawdopodobne, że odpisu dokonal podpisa-

15 Szmidt Z. M., Źródta Zbioru Karnkowskiego. (Teza doktorska przedstawiona na Wydziale Teologii Katolickiej U. W. w roku akad. 1953/54). Warszawa 1954 ss. VII, 211, ilustr. [maszynopis].

16 Szmidt Z. M., o. c., $31-36$. 
ry Maciej Łącki, kanclerz prymasa Latalskiego' ${ }^{17}$, co znacznie wzmocniłoby wiarygodność tej kopii.

Synod prowincjonalny zwołany był do Piotrkowa na dzień Wniebowstąpienia Pańskiego, t.j. na czwartek 15 maja 1539 r., rozpoczą swoje obrady dnia następnego, t.j. 16 maja i prowadzil je conajmniej przez 5 dni. Albowiem jeszcze 20 maja wysyła synod z Piotrkowa suplikę do Pawła III z prośbą o kanonizację św. Jacka Odrowąża. Podpisany jest prymas Latalski „una cum reverendissimis dd. episcopis \& capitulis in hac synodo sanctae (s) congregatis. Sigilla quatuor extra" (zapewne pieczęcie biskupów, co zgadzałoby się całkowicie ze wstępem do statutów synodu, gdzie jako obecni podani są prymas Latalski, Piotr Gamrat biskup krak'owiski, Łukasz Górka włocławski i Jakub Buczacki płocki) ${ }^{18}$.

Statuty uchwalone na synodzie obejmują krótki wstęp wyliczający obecnych uczestników synodu, oraz sześć obszernych nie numerowanych, lecz rubrykowanych rozdziałów, z których każdy zawiera szereg odrębnych fragmentów:

[I] Fidei catholicae et extirpationis haeresuum (s). K. 1v.-4v.

(1) In primis $><$ constitui debent. O powołaniu w diecezjach inkwizytorów.

(2) Qui quidem><occasionem praebeant. O treści kazań i źródlach literackich do nich.

(3) Et quoniam $><$ habitum decentem clericalem. O nauczaniu młodzieży i reformie obyczajów w szkołach.

(4). Inquirant etiam diligenter $><$ fide corrumpant. $O$ roztoczeniu nadzoru nad nauczycielami domowymi w domach szlacheckich.

(5) Decrevit etiam><lociordinarios imponenda. O nadzorze nad księgarniami i drukarzami i o biskupiej cenzurze prewencyjnej.

(6) Et quia multorum $><$ revocare dignaretur. $O$ odwołaniu do

17 K orytkowski J., Prataci i kanonicy katedry metropolitalnej gnieźnieńskiej. Gniezno 1883, T. 2, 519.

18 Suplika ta wydrukowana $u$ : Severinus Cracoviensis (Lubomlezyk), De vita, miraculis et actis canonizationis sancti Hyacinthi confessoris Ordinis Fratrum Praedicatorum libri quatuor. Rome, ex Typographia Gabiana Anno MDXCIV, pag. 245-246. (Estreicher, Bibliografia polska T. 21, 485). Wiadomość tę zawdzięczam uprzejmości ks. prof. dra Zdzisława Obertyńskiego, któremu na tym miejscu składam serdeczne podziçkowanie. 
kraju młodzieży studiującej $w$ Witemberdze i na innych uniwersytetach niemieckich zarażonych herezją.

(7) Et quia ex contemptu $><$ facere dignaretur. O stosowaniu statutów królewskich przeciwko tym, którzy lekceważą cenzury kościelne.

(8) Debent tamen $><$ fulminare praesumant. O nie nakładaniu cenzur w sprawach błahych.

(9) Roganda est etiam> < regiam maiestatem confirmatam. O przestrzeganiu praw ograniczających zydów.

(10) Delatum est > <afficere curet. O Jakubie z Ilży i jego pismach heretyckich.

[II] Libertatis ecclesiasticae manutenendae. K. $4 \mathrm{v} .-10 \mathrm{v}$.

(11) $\mathrm{Si}$. in comitis ><defecissuros pollicití sunt. o żądaniach szlachty, aby duchowieństwo okazało publicznie swe przywileje; o służbie wojskowej soltysów.

(12) Cum instaret clenus><innovaturos polliciti sunt. O udzielaniu zgody na sejmach na kontrybucję królewską.

(13) Item de retaxatione $><$ non consentient. O udzielaniu zgody na retaksację beneficjów.

(14) Roganda est $>$ <libertatem pertinens. O utrzymaniu w mocy jurysdykcji duchownej w sprawach przeciwko gwałcicielom immunitetów kościelnych.

(15) Admoniti diligenter > <penitus abrogetur. Interim tamen per nuntios $><$ indignus invenietur. O kanonicznym wyborze opatów oraz o królewskiej zgodzie na dokonany wybór opata na Eysej Górze.

(16) Sacrosancta synodus; satisfaciendo $><$ saeculari restituantur. Item causae mere spirituales $><$ in scriptis offerre curabunt. O rozgraniczeniu właściwości między sądami duchownymi a świeckimi.

(17) Supplicent etiam nunctii $><$ dotatione procedentis. O pozywaniu duchownych celem skazania na banicję za naruszenie statutów królewskich Olbrachta i Aleksandra w przedmiocie respektowania prawa patronatu królewskiego i prywatnego.

(18) Ex eo, quoniam Leo decimus><fulminatis absolverit. Sacra. provincialis synodus $><$ decrevit et constituit. $O$ sporze Beneddykta Izdbieńskiego $\mathrm{z}$ dolktorem Michałem z Pacanюwa o kanonię krakowska. 
(19) Ut autem bulla $><$ praedictae et debeant. O rezerwowaniu w kapitułach pięciu biskupstw cztenech kanonikatów dla duchownych doktorów pochodzenia plebejskiego.

(20) Consenserunt etiam domini > <illi providere promiserunt. O kanonikatach doktorskich w kapitułach kolegiackich.

(21) Promiserunt etiam domini $><$ pacto impediendo. O życzliwym traktowaniu kanoników katedralnych przez swoich biskupów.

(22) Promisit haec dominus $><$ oppressionem plurimorum. O wykonywaniu przez prymasa władzy legata urodzonego $w$ zgodzie $z$ prawem powszechnym.

(23) Quoniam propter $><$ et tenebuntur. O przyspieszeniu terminów chowania zwlok zmarlych biskupów.

(24) Cumque plerique abbates $><$ male alienata. O bezprawnych alienacjach majątku klasztorów.

(25) Decrevit etiam><generali Cracoviensi. O wysylaniu zakonników na studia na Wszechnicę Krakowską.

(26) Subditi dominorum abbatum $><$ iniungere dignaretur. O bezprawnym obciążaniu majątków klasztornych świadczeniami na rzecz króla.

(27) Synodus haec provincialis $><$ non gravatim. O zwolywaniu synodów prowincjonalnych tylko $w$ termiaie jessiennym.

(28) Decrevit haec sancta synodus $><$ divino sileret. O wydelegowaniu posłów od synơdu do Stolicy apostolskiej.

(29) De citatione regali ><paternitatem facta. O pozwie królewskim przeciwlko arcybiskupowi.

[III] Reformationis morum et vitae. K. $10 \mathrm{v}-13 \mathrm{v}$.

(30) Quia ex depravatis $><$ de manibus eorum requiratur. O konieczności karania występnych duchownych.

(31) Ut autem reformationem $><$ possint et valeant. O zatrudnianiu w kuriach biskupich wykształconych kapłanów, którzyby w zastępstwie biskupów nadzorowali walkę $z$ herezją i wykonywanie uchwał synodalnych.

(32) Reverendissimique domini $><$ non gravatim. O reformie obyczajów na dworach biskupich. 
(33) Decrevit haec synodus $><$ provinciales sanctiones. O obracaniu dochodów z kar pieniężnych, nakładanych na występnych duchownych, na światło w kościele lub na jałmużnę.

(34) Decrevit etiam $><$ desuper expressis. O nie podejmowaniu przez duchownych zastępstwa stron przed sądami świeckimi i nie piastowaniu urzędów świeckich.

(35) Cogant etiam $><$ habere praetendunt. O wizytowaniu parafii przez archidiakonów.

(36) In civitate et dioecesi Vielnensi $><$ non patiatur. o mnożeniu się $\mathrm{W}$ diecezji wileńskiej kościołów ruskich (prawosławnych).

(37) Pro reformanda><universitati constituat. O zebraniu funduszów na reformę Wszechnicy Krakownskiej.

(38) De parrochiali ecclesia><sortiant effectum. O inkorporacji parafii Dierząźna Wszechnicy Krakowskiej.

(39) Quia ecclesia collegiata Crusvicensis $><$ Wladislaviensis. O ruinie kolegiaty Kruszwickiej.

(40) Et quia fratres mendicantes><tolerari non possunt. O nadużywaniu przez zakony żeibrzące swych uprawnień płynących $z$ egzempcji i o konieczności uzyskania przez biskupów upoważnienia do reformowania tych zakonów.

(41) Reverendissimus olim dominus > <celerius conficiatur. O kanonikacie plockim fundi Gumnyno, pozostającym w posiadaniu Andrzeja Zebrzydowskiego.

(42) Dominus episcopus Culmensis $><$ se dismembrent. O przynależności diecezji chełmińskiej do prowincji gnieźnieńskiej.

[IV] Contributiones. K. $13 \mathrm{v}-15$.

(43) Haec sacra> < ordine infrascripto. O kontrybucji.

(44) In primis><cedere debet. O kontrybucji $z$ beneficjów opartych na czynszach.

(45) Vicarii perpetui > < duos grossos. O kontrybucji od niższego duchowieństwa i służby kościelnej.

(46) Item reverendissimi><reponantur in effectu. O kontrybucji biskupów, kapituł i o ogłoszeniu kontrybucji po diecezjach.

(47) Item ut domini $><$ sint contenti. O ustanowieniu i wynagrodzeniu kolektorów i subkolektorów. 
(48) Item decrevit synocus $><$ facere tenebuntur. O obowiązkach kolektorów i subkolektorów.

(49) A qua quidem $><$ contribui deberet. O zwolnieniu ad kontrybucji całej prowincji lwowskiej.

(50) Protestati sunt autem $><$ Plocensis submiserunt. O retaksacji niektóryich dochodów biskupúch.

[V] De poena non dicentium horas canonicas. K. 15-15v.

(51) Quoniam iura dicunt $><$ poenae defugiant. O represjach przeciwko duchownym zaniedbującym odmawianie brewiarza.

[VI] De usuris ex his provinciis tollendis. K. $15 \mathrm{v}-16$.

(52) Usurarum pestiferum crimen $><$ debere actionem. O zwalczaniu różnych postaci lichwy.

Porównując statuty z 1539 r. z wcześniejszymi statutami prowincjonalnymi doby Reformacji spostrzec można w nich sporo przejątków $\mathrm{z}$ dawniejszych trzech statutów, synodu łęczyckiego z 1527 r., ${ }^{19}$ synodu piotrkowskiego z $1530 \quad r .{ }^{20}$ i synodu piotrkowskiego z 1532 r. ${ }^{21}$. Przejątki te czasem są dosłowne lub prawie dosłowne, czasem problematyka przejęta $\mathrm{z}$ dawniejszych statutów prowincjonalnych otrzymała w statutach z 1539 r. nowe zaktualizowane sformułowanie. Najobfitszego materiału dostarczyły statuty łęczyckie z $1527 \mathrm{r}$.

I tak art. 1 statutu z $1539 \mathrm{r}$. jest częściową przeróbką i adaptacją art. 2 statutu z 1527 r., art. 2 opiera sie częściowo dosłownie na art. 3 , zaś art. 3 prawie dosłownie na art. 4 statutów łęczyckich. Art. 25 statutów z 1539 jest parafrazą i przypomnieniem dyspozycji art. 2 statutów z 1530 r., tyle że bez jego sankcji karnych. Art. 30 statutów z 1539 r. treścią swą nawiązuje do art. 9 statutów z $1527 \mathrm{r}$, również stylistycznie na nim się opiera. Art. 35 statutów z 1539 r. znów jest skróconym powtórzeniem nakazu zawartego $w$ art. 1 statutów synodu z 1532 r. Art. 36 jest krótkim powtórzeniem i podjęciem

19 Ulanowski B., Materiaty, o. c., 365-378 (41-54).

20 I b i d e m, 378-383 (54-59).

21 I bi de m, 383-386 (59-62). 
sprawy traktowanej w art. 8 statutów z 1527 r. Art. 37 rozwija zagadnienie, które było przedmiotem uchwały synodu z $1527 \mathrm{r}$. w końcowym zdaniu art. 4. Art. 40 statutów z 1539 r. ma za przedmiot tę samą problematykę, co art. 5 statutów z 1527 r., a nawet stylistycznie na nim się wzoruje, lecz stara się dać temu zagadnieniu inne nieco rozwiązanie. Art. 43-48 statutów z 1539 są prawie dosłowną parafrazą odpowiednich artykułów $31,20,22,24,25$ i 26 statutów z 1527 r. Art. 51-52 są dosłownym powtórzeniem art. 9 i 10 statutów z $1530 \mathrm{r}$. Widzimy więc, że conajmniej 17 artykułów synodu inspirowanych jest wzorami dawniejszych postanowień synodów prowincjonalnych. Ressta artykułów tych statutów ułożona została najpewniej na samym synodzie na podstawie materiałów przedłożonych podczas obrad, zależnie od aktualnej sytuacji i potrzeby. Charakterystyczną cechą omawianych statutów jest widoczne narastanie spraw kościelno-politycznych, w nich poruszanych. Wyraźnie odbijają się na ich postanowieniach wystąpienia i uchwały szlachty zgromadzonej w obozie pod Lwowem w $1537 \mathrm{r.}^{22}$

Statuty synodu z 1539 r. stały się w 3 lata później podstawą redakcji obszernych i arcyważnych statutów prowincjonainych pierwszego synodu arcybiskupa Piotra Gamrata odprawionego $\mathrm{w}$ Piotrkowie w 1542 r. ${ }^{23}$ Większość artykułów statutów z 1542 r., to dosłowne powtórzenie albo przeróbka poszczególnych fragmentów omawianego tu pomnika, przy czym przeróbka $\mathrm{w}$ większości przypadków polega na uzupełnieniu dosłownie przejętego wzoru przez mniejsze lub większe wstawki lub dodatki, niekiedy na opuszczeniu kawałka tekstu. Zależność statutów z 1542 r. od pierwowzoru ujawnia się również w ścisłym zachowaniu kolejności poszczególnych fragmentów. Poniżej zamieszczona tabela uwidoczni tę zbieżność. Artykuły statutów z 1542 r., które stanowią większą przeróbkę, oznaczone są gwiazdką.

22 Stanislai Górski Conciones in... conventu apud Leopolim de republica habitae a. D. MDXXXVII wydał Wojciech Kętrzyński. Arch. Kom. Histor. T. 1 (Scriptores Rer. Pol. T. 4) Kraków 1878, 1-87.

23 U 1 anow ski B., Materiaty o. c., 387-405 (63-81). 


\begin{tabular}{|c|c|c|c|c|c|}
\hline St. 1539 & St. 1542 & St. 1539 & St. 1542 & St. 1539 & St. 1542 \\
\hline 1 & 1 & \multirow{2}{*}{16} & $18^{*}$ & 35 & $35^{*}$ \\
\hline \multirow{2}{*}{2} & 2 & & 19 & 36 & 36 \\
\hline & $3^{*}$ & 17 & $20^{*}$ & 37 & $37^{*}$ \\
\hline \multirow{3}{*}{3} & $4^{*}$ & 18 & 21 & 38 & - \\
\hline & 5 & 19 & $22^{*}$ & 39 & - \\
\hline & $6^{*}$ & 20 & $23^{*}$ & 40 & $38^{*}$ \\
\hline 4 & 7 & 21 & $24^{*}$ & 41 & 40 \\
\hline \multirow{2}{*}{5} & $8^{*}$ & 22 & 25 & 42 & $41^{*}$ \\
\hline & $9^{*}$ & 23 & 26 & 43 & - \\
\hline 6 & 10 & 24 & $27^{*}$ & 44 & - \\
\hline 7 & \multirow{2}{*}{$11^{*}$} & 25 & $28^{*}$ & 45 & - \\
\hline 8 & & 26 & 29 & 46 & - \\
\hline \multirow{2}{*}{9} & $12^{*}$ & 27 & - & 47 & - \\
\hline & $13^{*}$ & 28 & - & 48 & $48^{*}$ \\
\hline 10 & $14^{*}$ & 29 & - & 49 & - \\
\hline 11 & \multirow{2}{*}{15} & 30 & $30^{*}$ & 50 & - \\
\hline 12 & & 31 & 31 & 51 & $50^{*}$ \\
\hline 13 & - & 32 & 32 & 52 & $51^{*}$ \\
\hline 14 & $16^{*}$ & 33 & 33 & - & - \\
\hline 15 & $17^{*}$ & 34 & 34 & - & - \\
\hline
\end{tabular}

* oznacza, że dany fragment uległ w statutach z 1542 r. znaczniejszej przeróbce. 
Powyższe zestawienie pozwala sformułować kilka stwierdzeń.

1. Ogromna większość fragmentów statutów z $1539 \cdot r$. weszla do statutów z 1542 r. Nie zostały przejęte jedynie fragmenty $13,27,28,29,38,39,43,44,45,46,47,49,50$, a wiẹc trzynaście fragmentów na ogólem 52.

2. Statuty z 1542 r. opierają się w ogromnej swej większości na statutach z 1539 r. Jedynie art. 39, 42, 43, 44, 45, 46, 47, 49 , a więc na 51 artykułów tylko 8 , nie zostały zaczerpnięte ze statutów z 1539 r.

3. Układ statutów, t.j. porządek artykułów został ściśle utrzymany.

4. Polowa artykulów z 1542 r. opartych na wzorach z 1539 r. uległa przeróbkom, uzupełnieniom lub skróceniom, nigdy jednak do tego stopnia, aby nie rozpoznać w nich już na pierwszy rzut oka bliskiego podobieństwa $\mathrm{z}$ fragmentem: statutów z 1539 r. Druga połowa artykułów zawiera przeróbki mniejszej wagi, raczej natury stylistycznej. Jedynie nieliczne artykuły recypują swój wzór dosłownie, bez żadnych przeróbek czy uzupełnien, jak np. art. 2, 15, 25, 31, 32.

Wniosek, do którego prowadzą powyższe stwierdzenia, jest prosty: statuty z $1542 \mathrm{r}$. sa nowym poprawionym, uzupelnionym i zaktualizowanym wydaniem statutów z 1539 r., którym przeto przyznac trzeba priorytet $\mathrm{w}$ formuliowaniu stanowiska Kościoła Polskiego w ważnych zagadnieniach kościelno-politycznych doby nasilającego się ruchu egzekucyjnego i potężniejącej fali Reformacji.

Poniżej puiblikujemy pełny tekst statutów synodu z 1539 r. z rękopisu BOZ 822.

\section{DECRETA SYNODI PIOTHRCOVIENSIS PRO FESTO ASCENSIONIS DOMINI ANNO EIUSDEMI 1539 [15.V.1539] CELEBRATAE.}

Sacra synodus provincialis Pyothrocoviae anno Domini $\mathrm{MD}^{\circ}$ XXXIX die Veneris in crastino Ascensionis Domini [16.V.1539] solemniter celebrata praesidente reverendissimo in Christo patre et domino domino 
Joanne de Lathalicze Dei gratia sanctae ecclesiae metropolitanae Gnesnensis archiepiscopo, legato nato et Regni Poloniae primate, praesentibus reverendissimils in Christo patribus et dominis dominis Petro de Gamrathis Cracoviensi, Luca de Gorka Wladislaviensi et Jacobo Buczaczki Plocensi eadem gratia episcopis, ecclesia cathedrali Posnanien si per mortem reverendissimi olim domini domini Stanislai de Olyesnycza episcopi Posnaniensis suo pastore destituta, praesentibus etiam omnium capitulorum metropolitanae ac cathedralium ecclesiarum huius provinciae nunctiis has infrascriptas laudabiles constitutiones decrevit et sancivit: [f. 1v]

[I] Fidei catholicae et extirpationis haeresuum [s].

In primis decrevit haec sancta synodus iuri communi et statutis provincialibus vetustioribus ${ }^{1}$ innitendo et eadem innovando, ut reverendissimi domini archiepiscopus et episcopi in suis dioecesibus servent inquisitores haereticae pravitatis, qui singulas dioeceses visitent et inquirant diligenter de haereticis notoriis et suspectis et illos iuxta sacrorum canonum dispositionem puniant aut ordinariis deferant puniendos, quorum unus in qualibet dioecesi presbyter saecularis vel regularis ex commissione et auctoritate speciali dominorum epliscoporum et non aliter deputari et constitui debent.

Qui quidem inquisitores haereticae pravitatis in omnibus ecclesiis praesertim parrochialibus super verbi divini contionatores diligentius inprimis superintendere debent, ut praedicetur populo verbum Dei secundum a scripturam solidam et per ecclesiam Romanam approbatam, nil penitus de novis doctrinis et haeresibus, quae nunc passim pullulant et contionibus suis admiscen[do].

Quod b ut facilius ad effectum deducere possint, statuit haec synodus sacrosancta antiquos [f. 2] canones innovando, quod domini archiepiscopus, episcopi eorumque in spiritualibus vicaril mandent per processus generales omnibus et singulis ecclesiarum parrochialium rectoribus eorumque vicariis et aliis verbi divini contionatoribus tam saeeularibus quam regularibus exemptis et non exemptis, ut prost Novum

a secundam or.

b Quot or.;

1 Art. 2 statutów synodu prow. lęczyckiego $z 3 . V I .1527$ r. Ulanow $\mathrm{s} k \mathrm{i}$ B., Materiaty do historii ustawodawstwa synodalnego $w$ Polsce $w$ w. XVI. Arch. Kom. Prawn. T. 1 (1895) s. 366 (48). 
et Vetus Testamentum opera beatorum Cipriani, Athanasii, Gregorii Nazanzeni, Origenis, Basilii, Crisostomi, Hilarii, Augustini, Ambrosii, Hyeronimi, Gregorii et Leonis, qui ea habere possunt, alioquin omelias per anni circulum dominicis diebus et singulis festivitatibus aptas, sacramentorum librum, lectionarium, antiphonarium, baptisterium, compotum, canones poenitentiales, psalterium cum interpretatione div'i Hyeronimi, vitam Christi, expositionem missae, Rationale divinorum, statuta provincialia nova et vetera, Theophilactum, Joannem Rophensem et Fabris contra Lutherum, et sermones Joannis Ekii habeant in eisque diligenter studeant et iuxta intelligentiam eorundem librorum Evangelium Christi populo tradant et interpretentur, ne ex diversis contionandi formulis scholasticisque disputationibus et seipsos in solido sacrae Scripturae intellectu confundant et auditoribus erroris confusionisque de seipsis occasionem ${ }^{c}$ praebeant.

Et quoniam viam omnis virtutis et veritatis Christifilde- [f. 2v] libus $a b$ ipsis cunabulis per magistros et praeceptores monstrari convenit, ut iuventus Christiana in scholis et triviis doctrinis sanis et melioribus imbuaturd, cum referat plurimum a iuventa sic vel sic asuescere, decrevit haec synodus, ut omnes scholae particulares in tota provincia visitentur annis singulis et reformentur diligenter, in eisque non legantur omnino libri Martini Lutheri, Melanchtonis et sequatium, ne ex eorum lectilonibus iuventus ab ipsis incunabulis inficiatur. Legantur autem in eisdem scholis et triviis diligenter libri Evangeliorum, Epistolae Pauli, Catho Mroralis, Isocrates, officila beati Ambrosii, decem praecepta, hymni, sequentiae, Ascensii officium per Quadragesimam, Cicero, Vergilihus e, Esopus et alii oratores et poetae approbati et in fide catholica minime suspecti. Curentque domini archiepiscopi et episcopi corumque in spiritualibus vicarii omnes scholas reformare diligenter in moribus et disciplina, et ut deinceps in vestibus saecularibus et laitcaillbus non incedant, sed genant habitum decentiem clericalem. Inquirant etiam diligenter per archidiaconos et inquisitores de paedagogis in domibus nobilium, ne aliquo libros suspectos legant liberis eorumidem, et eos in sana fide corrumpant. Decrevit etiam haec synodus sacrosancta, ut singulis annis in singulis dioecesibus per dominos lociordina-[f. 3]rios aut eorum delegatos bibliotecae ac libri venales in eis contenti visitentur ac diligentius revideantur. Quod si qui libri suspecti aut haeretici in illis reperientur, debent cremari et bibliopola puniri poena arbitrio ordinarii loci inponenda. Impressores autem librorum novos libros imprimere non audeant, nisi
c occasionis or.;
d imbuantur or.;
e Virilius or.; 
exemplaria primum revideantur per lociordinarios aut eorum delegatos sub poena graviori arbiitraria etiam [per] f lociordinarios imponenda. Et quia multorum nobilium et plebeorum filii contra edictum Regni publicum ${ }^{2}$ Withembergam et alias universitates Germaniae haeresi infectas studiorum gratia hactenu's proficiscuntur et ibidem commorantur, decrevit haec sancta synodus contra tales monitorium generale et speciale, ut infria certum tempus arbitrio domini archiepiscopi et episcoporum moderandum universitates praedictas deserant sub poena privationis beneficiorum, si beneficiati existunt, si autem non beneficiati, poena arbitraria per dominos lociordinarios imponendia. Decrevit etiam monitorium contra parentes, tutores et alios eisdem in praemissis sumptus et impenisas probabiliter facientes. Rogandaque est sacra regia maiestas per nuntios synodales, ut contra tales edicta in prioribus comitiis facta exequi et omnes ex universitatibus praedictis poenis gravioribus revocare dignaretur.

Et quia ex contempitu censurarum haereses et plurium [f. $3 v$ ] etiam suboriri consueverunt, capitanei vero locorum, licet executionem faciant contra nobiles censuras ultra annum legalem sustinentes $g$ iuxta statuta divorum Wladislai et Cazimiri ${ }^{3}$ Poloniae regum, tamen contra cives et plebeos illam facere minime volunt, licet statut is praedictis cautum sit, quod eandem executionem contra cuiuscumque status et conditionis homines indistincte facere teneantur. Roganda est etiam sacra maiestas regia per nuntios synodales, ut eiusmodi statuta, cum indistincte loquantur, indistincte etiam non solum cantra nobiles, sed cives et plebeos etiam debitae executioni demandari facere dignaretur. Debent tamen reverendissimi domini archiepiscopus et episcopi officiales suos cohercere, ne pro rebus parvi momenti censuras et praesertim interdictum ecclesiasticum fulminare praesumant. Roganda est etiam sacra maiestias regia per nuntios synodales, ut numerum et multitudinem Judaeorum in provincia Gnesnensi, praesertim vero in civitate Cracoviensi refrenare et ad numerum antiquum redigere synagogasque novas praesertim Cracoviae muro existructas destrui facere dignaretur,

f brak $w$ or.;

$g$ statuentes or.;

2 Edykt Zygmunta $I z$ daty Wilno, 4 lutego 1535 r. Ro manowski J. N., Otia Cornicensia, Poznań 1861, s. 231 - 232, przyp. 119;W. Zakrzewski, Powstanie $i$ wzrost Reformacji $w$ Polsce 1520 - 1572. Lipsk 1870 s. 235, przyp. 2 do rozdz. III. przesuwa date rocznq na 1534 i podaje $w$ wątpliwość datę dnìa i miesiaca.

3 Przywilej Wladystawa Jagietty z daty Kraków 31 stycznia 1433 r. $i$ jego potwierdzenie przez Kazimierza Jag. z daty Piotrków 26 7. kwietnia 1458 r. - Vol. Leg. (wyd. Pijar.) T. 1 s. $193-197$. 
licet enim in memoriam passionis Salvatoris nostri Judaei ab Ecclesia tolerantur, tamen numerus eorum augeri debet minime. Qui. [f. 4] iuxta sacrorum canonum dispositionem veteres synagogas reformare, novas autem praesertim ex muro minime construere possint. Quod denique Judaei in officiis theoloneorum vel aliarum publicarum exactionum per dominos temporales non praeficiantur, propter quae ius imperii in Christianos habere possent, quibus etiam extra commercia necessaria conversatio h cum Christianis, cohabitatio penitus prohibeatur. Et ne Christiani in servicio sint Judaeorum nutricesque Christianae ne ablactent foetus eorum vel econtra, id omnino districtius. sub poenis gravissimis inhibeant et in civitate Cracoviensi praeter sex testudines pro rebus eorum conservandis deinceps apud Christianos non habeatur iuxta compactata inter reverendissimum in Christo patrem et magnificum dominos episcopum et palatinum Cracoviensem modernum i desuper facta et per sacram regiam maiestatem confirmata.

Delatum est ad synodum sacrosanctam Jacobum de Ilza haeresiarcham plerosque sermones lingua Polonica excussisse et per Regnum Poloniae inter parochos et presbiteros dispersisse ac in domo cuiusdam nobilis in terra Vyelunensi receptaculum haberi. Decrevit haec synodus. ut domini laciordinarii per archidiaconos et visitatores suos super huiusmodi libellis et sermonibus diligentius inquirant et inventos igni tradant. [f. 4v] Quod denique reverendissimus dominus archiepiscopus Gnesnensis et receptatorem illum nobilem, cuius nomen ignorat, et ipsum haeresiarcham aprehendere et poenis iuris afficere curet.

\section{[II] Libertatis ecclesiasticae manutenendae.}

Si in comitiis Regni publicis quandocumque instaretur, ut clerus privilegia libertatum suarum, praesertim de non eundo ad bellum, publice monstrare debeat, temere et absque causa, id domini archiepiscopus et episcopi non faciant, nisi subesset causa urgens et legitima, praesertim ex quo privilegia libertatis ecclesiasticae in ecclesiis cathedralibus desuper clara habeantur. Idem de privilegiis scultetatis intelligendum est. Ad quad $j$ reverendissimus dominus archiepiscopus et episcopi liberaliter consenserunt et nil ea in re absque synodi provincialis consensu innovare promiserunt. Et ne sculteti ecclesiasticorum ad bellum proficiscantur, id se graviter et strenue defecissuros polliciti sunt.

Cum instaret clerus et facilitatem domini archiepiscopi et episoporum argueret, quod in comitiis publicis facile consentantur in syno-

h conservatio or.

i modernus or.;

j quot or.; 
dum provincialem celebrandam propter contributionem et alia onera in cle-[f. 5]rum imponenda, quod denique in spem contributionis futurae pecuniam mutuo dare consueverunt eorum celsitudines extra casum inevitabilis et desperatae necessitatis. Quinimmo in tali casu etiam absque synodi provincialis vel ad minus capitulorum suorum expresso consensu se nihil innovaturos polliciti sunt. Item de retaxatione $k$ bonorum facienda, si quoque in comitiis publicis adhuc illius mentio haberetur, quod absque synodi provincialis expresso consensu in illam non consentient.

Roganda est regia maiestas per nunctios synodales, ut statutum Wladislai ${ }^{4}$ regis de experiendol iure ecclesiastico contra violatores castrorum, oppidorum, villarum, decimarum et hominum ecclesiasticorum in eis degentium in suo robore conservetur, ut practicetur pro more veteri, cum sit unum ex statutis Regni ord thariis parem vim cum illis habens, quod denique occasione violentiae bonorum mobilium et immobilium ecclesiasticorum non dentur inhibitiones regales ad iudicia ecclesiastica, quandoquidem ipsimet iudices ecclesiastici pro discretione sua facile causas huiusmodi discutere possunt ac discernere, an spectant ad forum ecclesiasticum vel saeculare. Quod denique domini [f. $5 v$ ] episcopi in aula sacrae regiae maiestatis existenters illud statutum manuteneant et defendant pro virili, cum sit summum et unicum in corpore statutorum Regni $\mathrm{i}^{5}$ ad ecclesiasticam libentatem pertinens.

Admoniti diligenter per clerum reverendissimi domini archiepiscopus et episcopi promiserunt se deinceps in comitiis publicis in nova statuta libertatem ecclesiasticam tollentia absque consensu synodi provincialis non consentire, prout praedecessores eorum consenserunt in comitiis Pyothricoviensibus praeteritis statutum novum ${ }^{6}$ contra liberam et canonicam electionem abbatum $m$ in monasteriis, et ut soli nobiles monachi abbatiis $n$ praeficerentur, quod statutum novum, ut pote regulas et modum omnium ordinum religionum vivendi annihilans est ipso iure nullum, statum monachalem obligans minime, conditoresque eius a sacris canonibus et statutis provincialibus sunt excommunicati ipso facto facientes et consentientes. Et licet hoc ipsum statutum abro-

$k$ retraxacione or;

1 experigendo or.;

$\mathrm{m}$ ablatam or.;

n ablacijs or.;

4 Statut Wtadystawa Jagielty z 1432 (?) $r$. potwierdzony przez Kazimierza Jagiell. pod data Piotrków 3 grudnia 1457 r. - Vol. Leg. (wyd. Pijar.) T. 1 s. 112 - 114; J. W. Bandtkie, Jus Polonicum, Warszawa (1831) s. $235-239$.

5 Zbiór Easkiego z 1506 r. k. 63.

6 Vol. Leg. (wyd. Pijar.) T. 1 s. 521. Jest to uchwaka sejmu piotrkowskiego $z \quad 1538 \quad r$. 
gatione non indigeat, cum sit ipso iure nullum ex defectu potestatis et iurisditionis, nihilominus domini archiepiscopus et episcopi promiserunt se facturos et curaturos in Regni comitiis futuris, ut illud statutum, in quantum aliquod sit, pentus abrogetur.

Interim tamen per nunctios synodales roganda est [f. 6] diligenter sacra maiestas regia, ut pro sua innata iustitia et pietate ab executione statuti praedicti interim supersedere et electo abbati monasterii Sanctae Crucis in Calvo Monte consensum regium benigne praestare dignetur pro more veteri. Quod si electus ipse repertus fuerit indignus vel criminosus, dominus episcopus Cracoviensis, ordinarius suus, servatis servandis et habitis desuper probationibus, ut iuris est, sole meridiano clarioribus faciet circa confirmationem eius, quod de iure faciendum erit, salva nihilominus remanente illius monasterii canonica electione libera, in quantum modernus electus indignus invenietur.

Sacrosancta synodus, satisfaciendo votis et desideriis status saecularis et instantiae eorum in comitiis praeteritis7 desuper factis, descripsit synodaliter causas omnes ad forum et iudicium ecclesiasticum pertinentes in Corpore Iuris Canonici clausas, quae communiter in iudiciis ecclesiasticis practicantur. Quas causas pro more veteri reverendissimi domini archiepiscopus et episcopi se defensuros strenue promiserunt. Causie autem mere spirituales sunt haec: fides Catholica, haeresis, scisma, blasphemia in Deum et Sanctos eius, apostasia, decimarum, septem sacramentorum Ecclesiae, beneficiales, symoniaie, usurarum, presbytericidii, sacrilegii, cuiuslibet etiam confugientium o ad ecclesias, exceptis tamen quinque [f. 6v] casibus videlicet: nocturni depopulatoris $\mathrm{p}$ agrorum, aggressoris itinerum, publici proclamati furis aut ter in regestris reperti, incendiarii et immunitatis ecclesiasticae violatoris, quibus forum et immunitas ecclesiastica propter immanitatem q criminum non suffragentur, cum de ecclesiis et locis sacris extrahantur et iudicio suo saeculari restituantur.

Item causae mere spirituales sunt: maleficia, incantationes, sortilegia, raptus et violentiae ecclesiasticae, cuiruscumque censuum perpetuorum, qui terreni seu terragii, et conditionalium, qui viderkov v vulgo appellantur, sic agrorum $r$ seu dotium plebanalium, quae vulgo

o confugentium or.;

$p$ depopulatorum or.;

q immunitatem or.;

$r$ agrogrorum or;

7 Chodzi tu zapewne o dwa poprzednie sejmy, na których sprawy te byty poruszane, tj. o sejm piotrkowski $z 1538$ r. $i$ o sejm krakowski z 1538/39 r. - Por. do tego J. Sawicki, Z ksiag Metryki koronnej. Tekst pierwszych konstytucji sejmowych $w$ języku polskim $z$ r. $1543 w$ sprawie sadownictwa swieckiego $i$ duchownego. Teki Archin. T. 2: 1954 s. 79 i n. 
poszvathne appellatur, praesertim in quorum possessione ecclesiae et ecclesiasticae personae fuerunt a tempore diuturno et praescripto, necnon miserabilium et destitutarum personarum, quae labore manuum suarum victum quaerere non possunt, et legitimitatis seu natalium; sortitur etiam quis forum seu iudicium ecclesiasticum ratione contractus vel obligationis in iudicio ecolesiastico factaes et ratione delicti in ecclesiasticas pensonas et res mobiles ecclesiasticas commissi. Causae autem spirituali annexae sunt: iurispatronatus et dotis $t$ post divortium restituendae et repetendae. Causae autem mixti fori sunt: testamentorum et ultimarum voluntatum seu ordinationum. Quando testamenta et ultimae voluntates et ordinationes coram officio ecclesiastico vel notarib pub/f. 7/lico aut presbytero parochiano et testibus vel manu et sigillo propriis testatorum confirmantur $u$, his enim casibus: et ultimae voluntates hominum celerius et facilius executioni demandentur, liberum erit unicuique pro legatis et aliis omnibus in testamento contentis iure experiri coram iudicio quo velit, sive ecclesiastico, sive saeculari, et ubi causam inceperit, ibidem iure praeventionisv aandem finire teneatur. Ubi vero testamenta, ultimae voluntates seu ordinationes coram regia maiestate et officio saeculari vel civili quocumque, etiam coram sculteto $w$ et scabinis regnicolarum conficiuntur, eo casu pro legatis et aliis omnibus in tastamento contentis coram eodem iudicio et officio civili et villano, coram quo testamenta condita sunt, et non alibi iure experiendum erit, exceptis tamen legatis ad pias causas, quae inter causas mere spirituales computantur. Spirituales autem pro bonorum suorum terrestrium dominio w1 et proprietate et pro iniuriis eorundem iuri communi Regni subiectorum $x$ extra raptus et violentiae casus, ut praemittitur, iure terrestri Regni experiantur. Iniuriae autem sunt iuxta statutum Joannis Adalberti ${ }^{8}$ regis super limitibus, colonis fugitivis, capite occisi coloni et vulneribus. Si autem persona ecclesiastica saecularem extra casus praemissos ad iudicium spirituale $[f .7 v]$ citaverit, poena quatuordecim marcarum per ordinarium suum irremissibiliter puniatur. Hos autem articulos causarum

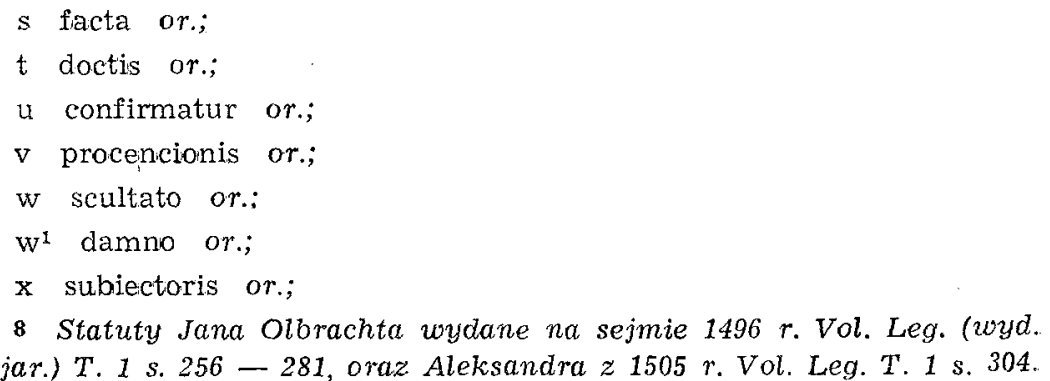
Pijar.) T. 1 s. 256 - 281, oraz Aleksandra $z 1505$ r. Vol. Leg. T. 1 s. 304. 
spiritualium nunctii synodales sacrae regiae maiestati in scriptis offerre curabunt.

Supplicent etiam nunctii praedicti sacrae regiae maiestati nomine totius congregationis synodalis, ne dentur deinceps citationes ad banniendum contra clerum extra casus statutorum Regni divorum Joannis Adalberti ${ }^{9}$ et Alexandri ${ }^{10}$ regum, quae iam sunt partim per Sedem apostolicam confirmata; quae citationes non dentur nisi in casu iurispatronatus regii vel laicorum veri ex fundatione et dotatione procedentis.

Ex eo, quoniam Leo decimus y pontifex maximus per bullam specialem 11 confirmavit eadem statuta ${ }^{12}$ pro nobilibus contra plebeos; ne recipiantur ad quinque ecclesias maiores cathedrales, cum deputatione iudicum perpetuorum, qui facta, sententias et censuras iudicum quorumcumque etiam $\mathrm{z}$ sacri auditorii rothae contra statuta et bullam easdem emanatas penitus tollerent et annihilarent, et reverendissimus in Christo pater dominus Bernardinus Dei gratia archiepiscopus Leopoliensis iudex perpetuus apostolicus per eandem bullam deputatus anno praeterito, die vero [f. 8] Iovis decima septima mensis octobris [17.X.1538] sententiam sacri auditorii rothae simul cum censuris in favorem doctoris Michaelis de Paczanow plebei et contra venerabilem aa dominum Benedictum Ischbynysky canonicum Cracoviensem, secretarium regium, ex utroque parente nobilem, occasione canonicatus et praebendae Cracoviensis instante sacra regia maiestate per certos commissarios suos videlicet: Clarae Tumbae et Chebdoviensem abbates retractaverit, nullas et irritas pronuntiaverit ac eundem dominum Benedictum a censuris praedictis per sacrum auditorium rothae fulminatis absolverit.

Sacra provincialis synodus sententiam et absolutionem praedictas ratas et gratas habens eisdem adhaesit et adhaeret firmiter, et ut deinceps perpetuis futuris temporibus talis processus observetur pro nobilibus contra plebeos in ecclesias quinque praedictas cathedrales se intrudentes, decrevit et constituit.

Ut autem bulla praedicta Leonis decimi huic Regno inclito et nobilitati eius in vim privilegii perpetui concessa in omnibus debitae executioni demandetur, decrevit haec synodus, ut capitula quinque ecclesiarum cathedralium praedictarum singula de consilio et assensu suo-

y dominus or.;

z $w$ or. wyraz powtórzony;

aa venerabiles or.;

9 -10 Statuty Jana Olbrachta j. w. oraz Aleksandra j. $w$.

11 Bulla Leona X $z 31$ lipca 1515 r. "Creditam nobis".

12 Statuty Jana Olbrachta na sejmie 1496 r. Vol. Leg. T. 1 s. 262265; oraz Aleksandra z 1505 r. Vol. Leg. T. 1 s. 302-303. 
rum reverendissimorum dominorum archiepiscopi et episcoporum deputent [f. $8 v$ ] duos canonicatus et totidem praebendas, ad quas futuris temporibus perpetuis duo doctores, etiam plebei, recipi possint et debeant, viidelicet unus in theologia et alius in utroque vel altero iurium, ultra duos canonicatus et praebendas antiquitus pro aliis ab duobus doctoribus deputatas, sic ut [in] ac singulis cathedralibus ecclesiis quinque praedictis sint duo doctores in theologia et duo in utroque vel altero iurium, ad quas etiam plebei recipi possint iuxta dispositionem bullae praedictae et debeant.

Consenserunt ad etiam domini archilepiscopus et episcopi, ponere in executionem statutum provinciale et bullam aliam Leonis decimi in novis statutis super titulc "De officio archidiaconorum" contentam ${ }^{\mathbf{1 3}}$, quibus cavetur, quod in singulis ecclesiis collegiatis provinciae Gnesnensis debent poni duю doctores actu residentes, videlicet unus in theologia et alius in utroque vel altero iurium. Quod tamen statutum et bullam pro hac vice in uno doctore tantum in executionem ponere et quilibet dominorum episcoporum ad primam vacantem praebendam in eisdem ecclesiis unum doctorem, ut praemittitur, instituere aut illi providere promiserunt.

Promiserunt etiam domini archiepiscopus et episcopi praelatis et canonicis ecclesiarum cathedralium deferre debitum [f. 9] honorem tanquam fratribus et membris suis immediatis, verbis eos non exasperando neque iurisditionern illorum capitularem iuramentis suis confirmątam aliquo pacto impediendo.

Promisit haec dominus archiepiscopus Gnesnensis iurisditione legationis natae in commissionibus et citationibus decernendis uti, prout communia ae iura disponunt, ne quod datum est in sufragium, vergere possit in oppressionem plurimorum.

Quoniam propter af diuturnam conservationem funerum et tardam sepulturam episcoporum defunctorum bona episcopatuum sede vacante multiphariam damnificantur, decrevit haec sancta synodus, ut executore's episcoporum defunctorum a die mortis in octo diebus ad minus et ad summum in quindecim diebus funera illorum sepeliri procurent, alioquin lapsis diebus praedictis capitula ecclesiarum et administratorem eligere et bona episcopalia inter se dividere debebunt et tenebuntur.

Cumque plerique abbates et abbatissae villas et bona monasteriorum suorum et iura patronatus ecclesiarum hactenus alienarunt ad fir-

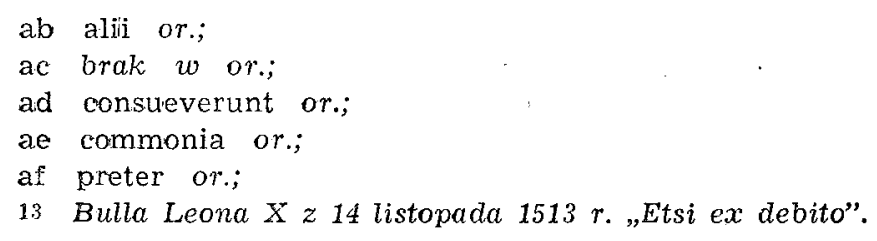


mam vel emphiteusìm concesserunt extra casum evidentis utilitatis et absque consensu episcopi loci, decrevit haec synodus, ut [f. 9v] domini ordinarii auctoritate eiusdem synodi decernant monitoria contra tales abbates et abbatissas, ut infra terminum unius anni taliter alienata omnia recuperent. Quod si lapso termino non recuperaverint, auctoritate praesentis synodi ordinarii compellant detentores ad restituendum male alienata.

Decrevit etiam haec sancta synodus, ut abbates et praelati religiosi iuxta statuta provincialia et constitutiones synodales servent fratres ordinum suorum in studio generali Cracoviensi.

Subditi dominorum abbatum praesertim Suleoviensis et Withoviensis gravantur novis et insuetis laboribus et angariis per factores regales et ab oppidis nonnullorum abbatum exiguntur currus bellici, qui per prius nunquam dabantur, aliqui etiam remoti compelluntur ferre stationes pecuniarias Cracoviam ad thezaurum sacrae regiae maiestatis. Petatur eadem maiestas regia per nunctios synodales, ut inconsuetos labores et angarias tollere et circa usitatos ac antiquos conservare, factoribusque suis et capitaneis, ne in illos pergravent, benigne iniungere dignaretur.

Synodus haec provincialis hoc tempore satis incommodo contra canones et statuta provincialia per [f. 10] dominum archiepiscopum indicta fuit, quam rem universus clerus in eadem constitutus gravabat et expostulabat plurimum supplicavitque eidem domino archipraesuli, ut deinceps, cum opus fuerit et necesse, synodum provincialem in autumno indicere et constituere dignaretur, ad quod sua reverendissima paternitas consensit non gravatim.

Decrevit haec sancta synodus, ut ex llla mittatur nunctius ad summum pontificem, qui nomine totius cleri huius Regni exponeret summo pontifici calamitates et pericula, quae crescunt in dies etiam in hoc Regno inclito propter variarum haeresuum augumenta, quae haereses ag nisi per concilium generale aliter omnino extirpari non possunt, alioquin et hic de ruina fidei brevi metuendum est. Qui denique persuaderet summo pontifici, ut concilium generale semel indictum continuaret quam primum et prosequeretur ah diligenter. Qui denique supplicaret vel potius praecustodiret summum pontificem et illam sanctam sedem, ne sacrae regiae maiestati et statui saeculari huius incliti Regni offerret vel promitteret deinceps decimam decimae ex proventibus ecclesiarum pro defensione Regni publica; nam eiusmodi promissio vel $[f .10 v]$ oblatio facere posset magnam turbam et discordiam inter status ecclesiasticum et saecularem et ruinam forte et in fide, cum spiritualia sine temporalibus diu subsistere non possunt, praesertim quod

ag haeres or.;

ah prosequeret or.; 
inevitabilis necessitas id minime exposcere videtur, ad quam obeundam domini archiepiscopi et episcopi deputarunt venerabilem dominum Joannem Wilamowsky cantorem Cracoviensem, secretarium regium. Vicarii ecclesiae cathedralis Wladislaviensis citati sunt Cracoviam ad tribunal regium pro theloneo suo, in cuius possessione fuerunt a tempore immemorabili, et habent desuper privilegia clara praedecessorum suae maiestatis, petatur eius maiestas per nunctios synodales, ut eosdem vicarios a termino et causa absolvere dignaretur, nam si eis hoc ipsum theloneum adimeretur ai ecclesia illa necessario in cultu divino sileret.

De citatione regali contra dominum archiepiscopum facta agant nunctii synodales apud regiam maiestatem, prout in alia instructione continetur per suam reverendissimam paternitatem facta.

\section{[III] Reformationis morum et vitae.}

Quia ex depravatis moribus et vita cleri haereses in ecclesia Dei, ut [plurimum] aj suboriri consueverunt, statuit haec sancta [f. 11] synodus, ut domini archiepiscopi et episcopi ad morum reformationem in clero, tam [in] ak capitibus, quam in membris solenniter procedant iuxta sacrorum canonum et statutorum provincialium veterum et novorum vim, formam et tenorem, puniendo et emendando clericos notorie excessivos, simoniacos, adulteros, usurarios et concubinarios publicos, saecularibus negotiis se immiscentes, in vestibus laicalibus incedentes, ceterisque criminibus irretitos. De qua reformatione plurima verba facere non expedit, quandoquidem de illa pleni sunt libri sacrorum canonum statutorumque provincialium novorum et veterum, modo et domini lociordinarii non oscitanter aut neglienter desuper executionem faciant, ne sanguis ovium de manibus eorum requiratur al.

Ut autem reformationem praedictam commodius facere valeant, am decrevit haec sancta synodus, ut domini lociordinarii in curiis et officiis suis servent viros doctos, Deum timenties, et praesertim in officiis cancellariae suae, unum ex praelatis vel canonicis ecclesiarum suarum cathedralium, qui vicem illorum, qui alioquin negotiis publicis sunt occupati, et extirpationibus haeresum et executionibus decretorum synodalium superintendere possint et valeant.

Reverendissimique dromini archiepiscopi et episcopi specimen et exemplum optimi odoris virtutum et bonae famae clero sibi subiecto de

\footnotetext{
ai admiteretur or.;

aj brak $w$ or.;

ak brak $w$ or.;

al negligatur or.;

am valerent or.;
} 
se prae-[f. 11v] beant, lectiones ex Sacra Scriptura in mensa sua post solennem orationem seu Benedicite adhibeant, cantilenas prophanas et saeculares non admittant familiaresque ecclesiasticos et saeculares in curiis suis reforment an diligenter, ne ceteris offendiculo existant, ad quod eorum celsitudines consenserunt non gravatim.

Decrevit haec synodus etiam, ut poenae pecuniariae clericorum excessivorum non in rem privatam officialium praedictorum, sed pro luminaribus ecclesiarum vel [ad] ao elemosinas pauperum de scientia et consensu ordinariorum convertantur, quod disponunt canones et provinciales sanctiones.

Decrevit etiam, ut clerici in placitis et iudiciis saecularibus non procurent exceptis causis ecclesiarum suarum, miserabilium personarum, suis et consanguineorum suorum; quod denique in officiis prophanis set factoriis saecularibus personis non serviant sub poenis in iure communi desuper expressis.

Cogant etiam domini archiepiscopi et episcopi auctoritate huius synodi et iuris communis, ut archidiaconi diligenter visitent parochias suas statutis a iure temporibus. Quorum visitationes soli ordinarii per se vel delegatos ap suos exequantur salvis privilegiis archidiaconorum, si quae desuper habere praetendunt.

In civitate et dioecesi Vielnensi multiplicantur in dies et aedificantur ecclesiae novae Ruthenicae contra sacros [f. 12] canones et vilipendium fidei scrosanctae Ecclesiae Romanae. Petatur sacra maiestas per nunctios synodales, ut id fieri non patiatur.

Pro reformanda universitate Cracoviensi matre nostra et proventi_ bus aq lectorum augendis ar et aliunde vocandis legista et duobus literarum humanarum professoribus reverendissimus dominus archiepiscopus Gnesnensis in hac sacra. synodo promisit se daturum centum ducatos auri in auro, Cracoviensis similiter centum auri in auro, Cuyaviensis centum florenos in moneta per mediam sexagenam et Plocensis etiam similiter centum, et super episcopum Posnaniensem futurum etiam centum similiter per mediam sexagenam synodus decrevit census perpetui de mensis eorum episcopalibus, ad quod capitula ecclesiarum praedictarum consensus suos praestare polliciti sunt, attento, quod hoc sacrum propositum in totius Regni utilitatem publicam vergere dinoscatur. Domini vero abbates in eadem synodo praesentes propter absentiam aliorum abbatum et religiosorum, et quod ea de re cum fratribus suis tractatus et consilia non habuerunt, distulerunt

an reservent or.;

ao brak $w$ or.;

ap delegatus or.;

aq proventus or.;

ar agendis or:; 
hoc negotium in aliam deliberationem et responsionem. Debent autem domini archiepiscopus et episcopi precibus supplicibus diligenter instare apud sacram maiestatem, ut et eius maiestas, ad tam sanctum, laudabile et necessarium opus de suis proventibus aliquem censum perpetuum praedictae universitati constituat. [f. 12v].

De parochiali ecclesia in Dzierzaszna dioecesis Cracoviensis iam dudum universitati Cracoviensi unita et incorporata, quae tamen unio effectum sortita non fuit, obtulerunt se facturos reverendissimi domini archiepiscopus Gnesnensis et episcopus Cracoviensis, ut eadem unio et incorporatio as suum sortiant effectum. Quia ecclesia collegiata Crusvicensis at desoluta est penitus et in structuris suis et in cultu divino, ita quod a multis retroactis temporibus in illa horae canonicae diurnae et nocturnae non peraguntur, reverendissimo domino et domino episcopo Wladislaviensi id referrente, cuius reverendissimae patennitatis iniunxit synodus, ut cogeret praelatos et canonicos illius ecclesiae redigere ad statum bonum praedictam ecclesiam tam in structuris, quam in cultu divino, qui cultus divinus in ea instauretur ad instar ecclesiae cathedralis Wladislaviensis.

Et quia fratres mendicantes praetextu exemptionum et privilegiorum suorum multa committere solent in contemptum fidei, cultus divini et iurisditionis ordinariae enervationem, nam excommunicatos per ordinarios vel corum officiales ad divina et sacramenta. Ecclesiae in ecclesiis suis admittunt, processus ordinariorum floccifaciunt et multis aliis criminibus et scandalis sunt obnoxii, vivuntque dissolute in ecclesiis et monasteriis suis tam virorum quam feminarum. Propter quod decrevit haec synodus sacrosancta, ut per nuntium iam ad summum pontificem deputatum agant reverendissimi domini archiepiscopus et episcopi pro commissione obtinenda saltim ad [f. 13] triennium pro personis et monasteriis praedictorum fratrum tam in capite quam in membris reformandis, et ne deinceps contraveniant his, quae iuris communis sunt, quae denique absque offendiculo au plurimorum tolerari non possunt.

Reverendissimus olim dominus Andreas Critius episcopus Plocensis canonicatum et praebendam Plocensem fundi Gumnyno av pro theologo praedicatore iam dudum designata providerat sororino suo venerabili domino Andreae Zebrzidowsky canonico Cracoviensi. Iniunctum est synodaliter reverendissimo domino episcopo Plocensi moderno, ut eandem praebendam evincat modis omnibus a praedicto domino Andrea, dando sibi gratiam de mensa episcopali aut aliam contenta-

\footnotetext{
as in corporatu or.;

at Crusvinensis or.

au defendiculo or;

av Gmnyno or.;
} 
tionem, et ut provideat pro more veteri de eadem praebenda alicui theologo insigni, qui in eadem ecclesia legere et verbum Dei proponere possit et valeat. Petenda est etiam sacra regia maiestas per nunctios synodales, ut per litteras suas auctoritatem suam regiam interpenat apud dominum episcopum Plocensem, ut hoc negotium celerius conficiatur.

Dominus episcopus Culmensis modernus cum capitulo swo citati non comparuerunt contra morem veterem in hac sacra synodo, protendentes se non ad Gnesnensem, sed ad regiam Rigensem provinciam pertinere. Decrevit sanca synodus, ut reverendissimus dominus archiepiscopus Gnesnensis decernat contra illos citationem ad declarandum propter inoboedientiam, attento, quod episcopatus ille fuit et est de corpore provinciae Gnesnensis, utpote ex parte bonorum episcopatus Plocensis fundatus. Petendalf. 13v]que sacra regia maiestas per nuntios synodales, ut huic [episcopo] aw et capitulo omnino iniungat,cum sit subditus regius et Regni, ne a corpore provinciae Gnesnensis se dismembrent.

[IV]. Contributiones.

Haec sacra provincialis synodus in complacentiam sacrae regiae maiestatis, supremi fidei catholicae, ecclesiarum et totius cleri defensoris, decrevit unanimiter contributionem duplam secundum antiquam taxam, pro hac vice tantum, pro festo sancti Nartini pontificis et confessoris futuro de proventibus istius anni per universum clerum tam saecularem [quam] ax regularem persolvendam ac ad thesaurum sclius suae maiestatis comportandam ay modo et ordine infrascripto:

In primis namque in hac contributione exigenda haberi debet ratio beneficiorum, quae in censibus nudis et $v i d e r k o w$ fundata sunt, ut tantum eis de praesenti contributione defalcetur, quantum per exactores Regni anno praeterito de censibus praedictis retentum vel solutum et simul cum tributo nobilium pro publica necessitate conversum est. Si autem solutio illa ex praedictis censibus contributionem anni praesentis excedet, id cum patientia beneficiati Reipublicae cedere debet.

Vicarii perpetui, altaristae ef mansionarii tam cathedralium quam collegiatarum et parochialium ecclesiarum iuxta taxas suas antiquas, si illas habent, praesentem solvant contributionem, exceptis tamen vicaritis perpetuis [f. 14] ecclesiae cathedralis Cracoviensis, qui ad instar vicariorum perpetuorum ecclesiae metropolitanae Genesnensis auctoritate huius sacri synodus $[s]$ ab omni contributione secundum antiquam taxam penitus debent esse liberi perpetue et in aevum, qui-

aw brak $w$ or.;

ax brak wor.;

ay comportandum or.; 
bus autem taxa antiqua non est, illi a qualibet marca usuali per duos grossos solvant. Manuales vero vicarii, gratialistae et presibyteri non beneficiati per tres grossos, ministri ecclesiarum, campanatores, organistae, cantores et sacristae quilibet solvat per duos grossos.

Item reverendissimi domini archiepiscopus et episcopi debent quisque ad capitulum suum in manus collectorum generalium contributionem suam consuetam quamprimum reponere; ut demum praelati, canonici, abbates et clerus universus contribuant, ad quord processus et mandata sua per dioecesim suam mittant quamprimum; et quod capitula ecclesiarum non prius contribuere teneantur, antequam contributiones dominorum archiepiscopi et episcoporum ad capitula mittantur et in manus collectorum az reponantur in effectu.

Item ut domini archiepiscopus et episcopi deputent duos collectores generales ex praelatis vel canonicis - ecclesiarum suarum, qui salarii nomine habebunt per quinque marcas, qui collectores ba in consuetis locis dioecesum succollectores deputabunt, quorum singuli salario trium marcarum sint contenti.

Item decrevit synodus, ut succollectores pecunias contributionis deferant ad metropolitanam et cathedrales [f. 14v] ecclesias in manus generalium collectorum, quibus de eadem rationem faciant sufficientem. Collectores vero generales pecuniam contributionis in capitulis metropolitanae et cathedralium ecclesiarum reponant et rationem totius contributionis illius dioecesis capitulo faciant, capitula vero contributionis rationem synodo provinciali proxime futuro facere tenebuntur.

A qua quidem contributione praesentis anni sacna synodus reverendissimum dominum archiepiscopum Leopoliensem totamque provinciam suam liberos et absolutos dimisit ex certis causis animum suum moventibus, ratis nihilominus manentibus decretis synodorum praecedentium de retaxatione $\mathrm{bb}$ beneficiorum ecclesiasticorum ac de contributione in provincia praedicta,14 ubi summa pecuniarum certa pro aliqua necessitate imminenti per universum clerum contribui deberet.

Protestati sunt autem solenniter nuntii capitulorum et domini abbates, quod deinceps futuris. perpetuis temporibus contribuere nolunt secundum hanc taxam antiquam, omnino iniustam et inaequalem, ubi et in quantum contributio aliqua pro tempore necessario esset decernenda, sed secundum taxam novam moribus [s] utentium semel approbatam. Qua protestatione permota decrevit sacra synodus, ut reverendissimi domini archiepiscopus, Posnaniensis et Plocensis episcopi in

az collatorum or:;

ba collatores or.

bb retraxacione or;

14 Art 30 statutów synadu prowincjonalnego lęzyckiego z 3 lipca 1527 r. - Ula nowski, Materiaty o.c. s. 375 - 376 (51-52). 
dioecesibus suis molendina mensarum suarum omnia et alios, qui antea fideliter et mediis iuramentis non fuerunt taxati proventus, denuo retaxent et retaxationem huiusmodi ad synodum provincialem futuram compor-[f. 15]tare procurent sub poena mille florenorum ad usum pium et deificum [?] per synodum futuram applicandorum ac per eandem synodum exigendorum, ad quod se sponte et libere dominus archiepiscopus et episcopus Plocensis submiserunt.

[V] De poena non dicentium horas canonicas.

Quoniam iura dicunt beneficium dari ob officium, ad horas quoque canonicas domino Deo veluti certum pensum quotidie persolvendas quemque beneficii possessorem arctissimis vinculis esse obstrictum, altero namque, quod patrimonio Christi, beneficio scilicet fruatur, altero, quod ondine, cui horae canonicae connexae sunt, sit insignitus, plerique tamen clerici etiam insignes tantam de se domino Deo obligationem minime curantes in grave animarum suarum periculum inque decoris clerici perniciem malitiosum illum servum imitati evangelicum, qui talentum luchri faciendi [causa] bc a Domino sibi commissum habens in terram defodit nullum Domino fructum quin potius ex negligentia damnum sibique ob hoc Domini cum pernicie indignationem allaturum, cum horarum divinarum censum minime persolvere idque pretiosum talentum a domino Deo lucrandi causa illis commissum negligere non horrescunt. Proinde haec reverendissima synodus dominos ordinarios orat, cohortatur atque eorum conscientiis iniungit diligenter, ut clericas bd tales perquirant ac iustis ex arbitrio eorum poenis percellant, quo et hi etiam inviti in Deo debitum obsequium [f. 15v] adigantur aliique be tantam insanam animi indulgentiam exemplo poenae defugiant.

[VI] De usuris ex his provinciis tollendis.

Usurarum pestiferum crimen quam longe lateque se defudit, quamque vetere pontificum conniventia bf in his provinciis coaluerit bg vel nemo est, qui non videat. Cum enim circa mutuum, quod ex benivolentiae officiique bh fonte profluens natura sui gratuitum esse debeat, sed nec quidquam bi ex eo sperandum esse bj, tam divinae quam humanae

\footnotetext{
be brak wor.;

bd cleros or.;

be aliisque or.;

bf comminencia or.;

bg cohaluerit or.;

bh officiisque or.;

bi quitquam or.;

bj essset or.;
} 
leges enuntiant, plurimi tamen sunt in his provinciis, qui mutuum quidem dant, sed non gratuito neque officio benivolentiae, cum ex pignore bonorum quorumcumque census proventusque a se receptos in sortem mutui non computando eam quam mutuarunt bk pecuniarum quantitatem integram nihilominus repetunt, in grave animarum suarum detrimentum et proximi iacturam, non intelligendo in hoc acerrimum crimen usurae permanere. Et quamvis tam iure communi, quam statutis provinciae nostrae antiquis, quae in titulo De usuris continentur, ${ }^{15}$ abunde ei crimini in obvium itum sit, et quo pacto admittatur bl, quo etiam modo puniendum sistendumve, quaeque eius sit satisfactio, abunde prospectum sit, tamen quoniam eadem illa tam salutaria statuta per malam omnium rerum novercam negligentiam diutino situ hactenus obsoleta sunt in Christifidelium grave dispendium, ut itaque ea per-[f. 16]nicies a Christifidelibus devitetur ex hisque provinciis nostris tollatur commodius, auctoritate praesentis provincialis concilii innovamus eademque illa vetera de usuris statuta decernendo, ut reverendissimi domini pontifices per litteras processuum suorum districte praecipiant verbi Dei contionatoribus, quo id crimen usurae in contionibus annuntient populo detestenturque bm ac quomodo committatur, declarent secundum eorundem antiquorum statutorum late comprehensam doctrinam. Idque maxime faciant temporibus Adventus Domini et Quadragesimae. Addant insuper eos tales in futurum absolvi non posse, nisi restituant, quod hoc nomine receperint, sed neque in sacro loco sepeliri posse, si publice foenerarint, hisque, qui vel iam dederint vel daturi sunt usuram, in foro ecclesiastico ad expetitionem eiusdem iure bono competentem dari debere actionem.

Mathias Ląnczkj cancellarius reverendissimi domini archipraesulis Cinesnensis.

\section{ZUSAMMENFASSUNG.}

Unter dem Titel „Analecta aus Handschriften Warschauer Bibliotheken" bringt der Verfasser den Ertrag seiner neuesten Forschungen aus kanonistischen Handschriften der Universitätsbibliothek und der Nationlalbibliothek in Warszawa. In Kapitel I wird eine verschollen geglaubte, erst im Jahre 1952 aus Privatbesitz erworbene Hs. Universitätsbibliothek Inv. Nr. 224 behandelt. Die Papierhandschrift ist in der

\footnotetext{
bk mutarunt or.;

bl adimatur or,;

bm detestentque or.;

15 Statuty synodalne wielunsko-kaliskie Mikotaja Traby z r. 1420... wydali X. Jan Fijatek i Adam Vetulani. Kraków 1915-1951 s. 101-105: Ksiega V. art. (9) De usuris.
} 
1. Hälfte des XV, Jh. in der Posener Diözese entstanden. Sie enthält sorgfältig angefertigte Kopien einiger Stücke juristischen Inhalts, die für die Kirchenrechtsgeschichte Polens, insbesondere aber für die damals aufflammenden Gegensätze zwischen dem geistlichen Stand und der Schlachta, dem Adelsstand des Königreichs, nicht ohne Bedeutung sind. An der Spitze steht eine gute, zeitgenössische Kopie der um das Jahr 1420 publizierten Diözesanstatuten des Posener Bischofs Andreas Łaskarz (Laskary). Der Text dieser Statuten ist bereits veröffentlicht (S a wi cki, Concilia Poloniae. Bd. 7. Die Synoden der Diözese Poznań und ihre Statuten. Poznan 1952). Ein bisher unbekanntes Meßformular contra scismaticos dürfte aus dem Jahre 1440 stammen und in Zusammenhang mit der Union von Florenz (1439) gebracht werden. Die hier abgedruckte „Forma inquisitionis in visitatione archidiaconi in parrochiis" ist ein interessanter Beitrag zur Geschichte der Sendgerichtsbarkeit der Archidiakone im XIV und XV. Jh. Die hier erstmalig publizierte „Forma visitationis" nimmt ausdrucklich auf die Posener Diözese Bezug, verrät jedoch eine sehr enge Verwandtschaft, ja sogar oft eine wörtliche Ưbereinstimmung mit einer 1888 von $\mathrm{Abr}$ a h a m veröffentlichten, analogen Fragenliste für die Diözese Włockawek aus der Mitte des XIV. Jh. Da beide Fragenformulare zweifellos nach derselben Vorlage gearbeitet sind, obwohl sie auch mitunter recht charakteristische Abweichungen aufweisen, beide Diözesen aber derselben Kirchenprovinz Gniezno angehören, liegt die Vermutung nahe, daß wir es mit zwei lokalen Varianten einer für die gesamte Kirchenprovinz eingeführten und den Suffraganbistümern zur Einführung und Anwendung empfohlenen, noch aus dem XIV. Jh. stammenden Instruktion für die Archidiakone zu tun haben, denen die örtlichen und zeitlichen Umstände ihr etwas gesondertes, den gegebenen Verhältnissen angepaßtes Gepräge verliehen hatten. Die endgültige, in der Hs. niedergelegle Fassung der Posener „Forma inquisitionis" setzt der Verfasser in die Zeit zwischen 1406 und 1420. Das letzte der hier gedruckten Stücke, die „Responsiones prelatorum et cleri Cracoviensis diocesis ad articulos dominorum nobilium regni Polonie nuper presentatos" bringt eine bisher unbekannte Fassung der in einer anderen, recht verschiedenen Fassung gedruckten (He y zman n, Starodawne Prawa Polskiego Pomniki [Alte polnische Rechtsdenkmäler] Bd. 4, 1875, s. 90-100), fälschlich als "Concordata dominorum baicorum cum prelatis ecclesie" betitelten und in das Jahr 1440 gesetzten Denkschrift des Krakauer Klerus unter Führung des berühmten Krakauer Bischofs und Kardinals Zbigniew Oleśnicki, als Antwort auf die Gravamina des Adelsstandes des gesamten Königreichs Polen. Sowohl Datum, als auch die näheren Umstände und der Ausgang dieser schwerwiegenden Verhandlungen ist im bisherigen Schrifttum stark umstritten (Bobrzyński, Ulanowski, Balzer, Prochaska, H. F. Schmid). Die Abfassung der Tenkschrift ist wohl in das Jahr 1435 zu setzen. Der Verfasser 
gibt der Uberzeugung Ausdruck, daß die Auffindung einer neuen Fassung der Denkschrift ein neues, bisher nicht berücksichtigtes Element in der quellenmäßigen Grundlage der ganzen Kontroverse bildet und daß nunmehr die ganze Frage erneut zu überprüfen und an Hand des neuen Textes zu bearbeiten wäre. Der restliche Teil der Hs. enthält die Kopien längst bekannter Urkunden, betreffend die Regelung der Zehentpflicht, gleichsam als Ergänzung zu dem in den "Responsiones" behandelten Material.

Kapitel II. Im Handschrifteninventar der Universitätsbibliothek in Warszawa sind unter Nr. 459 handschriftliche Eintragungen in einem Altdruck vom Jahre 1527, enthaltend eine amtliche von Primas Johannes Easki veröffentlichte Sammlung von Konstitutionen der Gnesener Provinzialkonzilien, vermerkt. Die Eintragungen stammen von einer geübten Hand aus der Hälfte des XVI. Jh. und umfassen drei Gruppen. Die erste Gruppe bringt einige z. T. ungedruckte Protokollauszüge von Sitzungen des Posener Domkapitels aus den Jahren 1462 - 1486, betreffend die Regelung vermögensrechtlicher Fragen. Die zwreite Gruppe enthält leider nur allzuknappe Fragmente von bisher völlig unbekannten Synodalstatuten der Posener Diözese vom 27. April 1506, was insoferne von Wichtigkeit ist, als der bisherigen Forschung die Tatsache der Verabschiedung von Diözesanstatuten auf der Synode von 1506 überhaupt nicht bekannt war. Die dritte Gruppe enthält Auszüge aus den umfangreichen Statuten des Provinzialkonzils von Piotrków vom J. 1542. Der Text des Altdruckes ist ansonsten ziemlich reich glossiert. Es ist wohl das Handexemplar eines Posener Domherrn, zugleich Lehrers des kanonischen Rechts an der vom Bischof Johannes Lubrański im Jahre 1519 in Poznań gegründeten Akademie seines Namens.

In Kapitel III werden die in einer Hs. der Nationalbibliothek in Warszawa, Nr. BOZ 822, neuentdeckten, bisher nur aus zwei Fragmenten bekannten, umfangreichen und reiches Material zur kirchenpolitischen Lage enthaltenden Statuten des im Jahre 1539 in Piotriów tagenden Provinzialkonzils besprochen und erstmalig ediert. Die Statuten schäpfen teilweise aus älteren. Provinzialstatuten aus den Jahren 1527, 1530 und 1532 , die als Vorlagen gedient haben, teilweise bringen sie vollkommen neues und selbständig, entsprechend den aktuellen Bedürnissen, verarbeitetes Material. Ihre Bedeutung liegt jedoch vor allem darin, daß sie ihrerseits als Vorlage für die wichtigen Provinzialstatuten vom Jahre 1542 gedient haben und von den letzteren fast zur Gänze rezipiert worden sind, wobei die einzelnen Artikel in der Regel ergänzt, umredigiert oder sonstwie, den Erfordernissen der politischen Lage gemäß, entsprechend zurechtgestutzt wurden. Die Statuten v. $T$. 1539 sind eine neue wichtige Quelle zur Synodalgesetzgebung der pol nischen Kirche der Reformationszeit. 